\title{
A study of uncertainties in the sulfate distribution and its radiative forcing associated with sulfur chemistry in a global aerosol model
}

\author{
D. Goto ${ }^{1}$, T. Nakajima ${ }^{1}$, T. Takemura ${ }^{2}$, and K. Sudo ${ }^{3}$ \\ ${ }^{1}$ Atmosphere and Ocean Research Institute, The University of Tokyo, Kashiwa, Chiba, Japan \\ ${ }^{2}$ Research Institute for Applied Mechanics, Kyusyu University, Kasuga, Fukuoka, Japan \\ ${ }^{3}$ Graduate School of Environmental Studies, Nagoya University, Nagoya, Aichi, Japan
}

Received: 23 December 2010 - Published in Atmos. Chem. Phys. Discuss.: 19 April 2011

Revised: 9 October 2011 - Accepted: 24 October 2011 - Published: 3 November 2011

\begin{abstract}
The direct radiative forcing by sulfate aerosols is still uncertain, mainly because the uncertainties are largely derived from differences in sulfate column burdens and its vertical distributions among global aerosol models. One possible reason for the large difference in the computed values is that the radiative forcing delicately depends on various simplifications of the sulfur processes made in the models. In this study, therefore, we investigated impacts of different parts of the sulfur chemistry module in a global aerosol model, SPRINTARS, on the sulfate distribution and its radiative forcing. Important studies were effects of simplified and more physical-based sulfur processes in terms of treatment of sulfur chemistry, oxidant chemistry, and dry deposition process of sulfur components. The results showed that the difference in the aqueous-phase sulfur chemistry among these treatments has the largest impact on the sulfate distribution. Introduction of all the improvements mentioned above brought the model values noticeably closer to in-situ measurements than those in the simplified methods used in the original SPRINTARS model. At the same time, these improvements also brought the computed sulfate column burdens and its vertical distributions into good agreement with other AEROCOM model values. The global annual mean radiative forcing due to the direct effect of anthropogenic sulfate aerosol was thus estimated to be $-0.26 \mathrm{~W} \mathrm{~m}^{-2}\left(-0.30 \mathrm{~W} \mathrm{~m}^{-2}\right.$ with a different $\mathrm{SO}_{2}$ inventory), whereas the original SPRINTARS model showed $-0.18 \mathrm{~W} \mathrm{~m}^{-2}\left(-0.21 \mathrm{~W} \mathrm{~m}^{-2}\right.$ with a different $\mathrm{SO}_{2}$ inventory). The magnitude of the difference between original and improved methods was approximately $50 \%$ of the uncertainty among estimates by the world's global aerosol models reported by the IPCC-AR4 assessment report. Findings
\end{abstract}

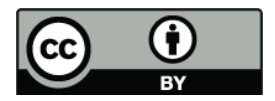

Correspondence to: D. Goto (goto@aori.u-tokyo.ac.jp) in the present study, therefore, may suggest that the model differences in the simplifications of the sulfur processes are still a part of the large uncertainty in their simulated radiative forcings.

\section{Introduction}

Secondary aerosols are formed from their precursor gases in the atmosphere through condensation and nucleation processes after oxidation. They have various components such as sulfate $\left(\mathrm{SO}_{4}^{2-}\right)$, ammonium, nitrate, and a part of organic matter (secondary organic aerosol; SOA). Most secondary aerosols are considered to be major anthropogenic aerosols (e.g. Seinfeld and Pandis, 1998). Also, they can become cloud condensation nuclei $(\mathrm{CCN})$ and may have a large impact on the earth's radiation budget through the aerosol indirect effect (e.g. McFiggans et al., 2006). Proper estimates of the radiative impact due to the anthropogenic aerosols, therefore, need accurate modeling studies to predict the secondary aerosols.

Schulz et al. (2006) presented the AEROCOM model inter-comparison of anthropogenic aerosol direct radiative forcings calculated by nine global aerosol models. They showed that the magnitudes of the radiative forcing due to total anthropogenic aerosols range from $+0.04 \mathrm{~W} \mathrm{~m}^{-2}$ to $-0.41 \mathrm{~W} \mathrm{~m}^{-2}$. Also they showed that the radiative forcing due to anthropogenic sulfate aerosol is estimated to be between from $-0.16 \mathrm{~W} \mathrm{~m}^{-2}$ to $-0.58 \mathrm{~W} \mathrm{~m}^{-2}$; this range is larger than those due to black carbon (BC) and organic carbon (OC) aerosols. This comparison suggests that a large portion of the differences in the radiative forcings of total anthropogenic aerosols among models still stem from modeling of the radiative forcing due to sulfate component.

Published by Copernicus Publications on behalf of the European Geosciences Union. 
(a)

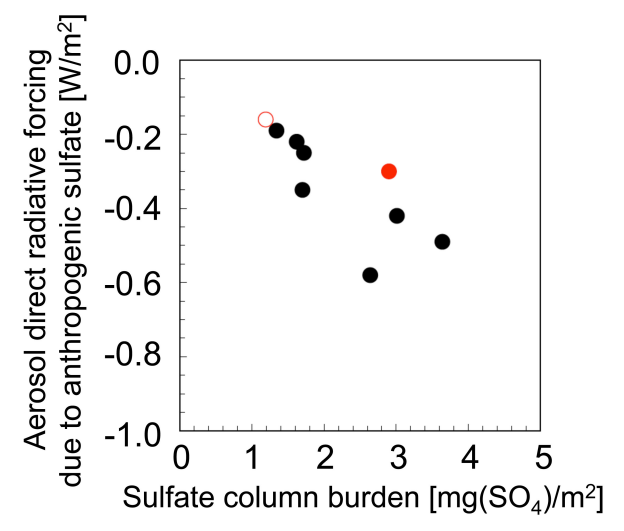

(b)

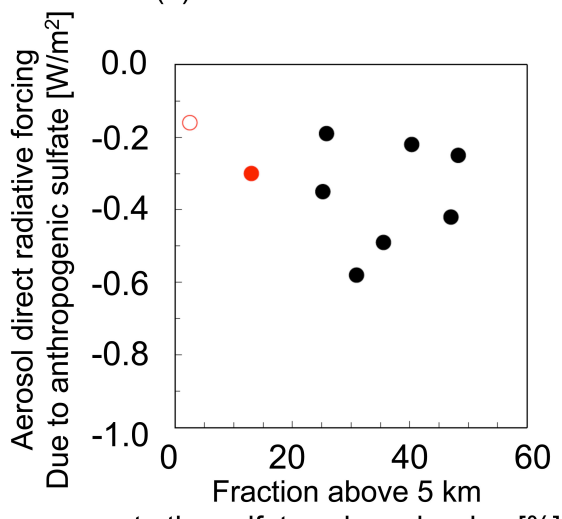

Fig. 1. Correlation (a) between sulfate column burden (x-axis) in $\mathrm{mg}\left(\mathrm{SO}_{4}^{2-}\right) \mathrm{m}^{-2}$ and aerosol direct radiative forcing due to anthropogenic sulfate aerosols under the all-sky condition at the top of atmosphere (y-axis) in $\mathrm{Wm}^{-2}$ and (b) between fraction above $5 \mathrm{~km}$ to the sulfate column burden (x-axis) in percentage and aerosol direct radiative forcing due to anthropogenic sulfate aerosols under the all-sky condition at the top of atmosphere (y-axis) in $\mathrm{Wm}^{-2}$. The all data in closed circles in black are given by Schulz et al. (2006) and Textor et al. (2006). The closed and open circles in red represent the result in this study and the original SPRINTARS.

Figure 1 shows scatter plots to show relations of global annual mean values of sulfate column burden and sulfate fraction above $5 \mathrm{~km}$ to its column burden with the aerosol direct radiative forcing due to anthropogenic sulfate aerosols using the AeroCom data from Textor et al. (2006), Schulz et al. (2006) and the present study. The figure can help us to understand how the relations among these key quantities are scattered showing that models still have problems in realistic simulation of the radiative forcing due to problems in modeling of both the sulfate burden and stratification. Figure 1a shows an obvious tendency that the aerosol direct radiative forcing increases as the sulfate column burden increases, though the rate of increase differs among models. Most sulfate aerosols are scavenged below $5 \mathrm{~km}$, so that there is a model tendency of increasing sulfate column burden with increasing sulfate fraction above $5 \mathrm{~km}$. In Fig. 1b, however, we do not find any systematic tendency between the aerosol direct radiative forcing and the sulfate fraction above $5 \mathrm{~km}$ if we include all the data points, reflecting the fact that a change in the height of a non-absorbing aerosol layer does not cause a noticeable change in the radiative forcing at the top of atmosphere. The results given by Fig. 1 lead us to a conclusion that uncertainties in the radiative forcing due to anthropogenic aerosols among global aerosol models are largely derived from the differences in the sulfate column burden and to a lesser extent in its vertical distribution.

Moreover, a detailed investigation of the results suggests that the different sulfate distributions among global aerosol models possibly come from model differences in both formation and loss processes. The major formation process of sulfate is that sulfur dioxide $\left(\mathrm{SO}_{2}\right)$, as a precursor for sulfate, is oxidized in the atmosphere and turns to sulfuric acid and then to a particle through condensation or nucleation pro- cesses. The major loss process of sulfate has been considered to be wet deposition because of its typical size ranging from 0.1 to $1 \mu \mathrm{m}$ with its high CCN efficiency (e.g. Rasch et al., 2000). Most global models adopt a similar method for the wet deposition, i.e. in-cloud and below-cloud scavenging, using the ratio of the aerosol in the cloud to that in the interstitial phase and use similar magnitudes of the ratio (Textor et al., 2006). This suggests the wet deposition modeling is likely not the major reason for the difference in the sulfate distribution, whereas a difference in the cloud and precipitation process modeling can be one of the major reasons. In addition, a difference of the transport is beyond this study.

The other problem is the difference in the sulfate formation process. Since Langner and Rodhe (1991) first published the global sulfur cycle model, sulfur chemistry modeling studies indicate that the major process of the sulfate formation is the $\mathrm{SO}_{2}$ oxidation in the aqueous phase by hydrogen peroxide $\left(\mathrm{H}_{2} \mathrm{O}_{2}\right)$ and ozone $\left(\mathrm{O}_{3}\right)$ (e.g. Roelofs et al., 2001). Figure 2 shows ratios between wet deposition flux and sulfate production rate in the aqueous-phase oxidation in global annual averages using results obtained by various global aerosol models. We can expect that the removal amount of $\mathrm{SO}_{2}$ from the atmosphere increases as the ratio decreases when the sulfate production remains the same. In Fig. 2, the GISS and SPRINTARS models, which also have lower sulfate column burden as shown in Schulz et al. (2006), show substantially low values of the ratio to the other models. As a result, the difference in the modeling of $\mathrm{SO}_{2}$ production in the aqueous phase can cause the difference in the sulfate distribution.

The question now arises: What is the main reason causing the differences in the aqueous-phase sulfur chemistry? One of the possible reasons is that the method of simplification of the process, which is necessary with limited computer 
burden allocated in the global aerosol model computation, is different among global aerosol models. It is important to quantify the impact of this simplification by comparing against models with more physical, and/or complex, representation of the sulfur cycle. The algorithms adopted in a global aerosol model SPRINTARS (Takemura et al., 2000, 2002, 2005) are described in Sects. 2 and 3. Investigation of impacts of different methods for sulfate formation is shown in Sect. 4. Sulfate distributions are computed in Sect. 5 and 6 with a more physical-based method in order to compare with observations. A discussion of the impact on aerosol direct radiative forcing is given in Sect. 7.

\section{Sulfur process}

In most three-dimensional global aerosol models, three pathways of sulfate formation are considered (e.g. Textor et al., 2006). The first path is aqueous-phase oxidation of $\mathrm{SO}_{2}$ by $\mathrm{H}_{2} \mathrm{O}_{2}$ and $\mathrm{O}_{3}$. The second one is gas-phase oxidation of $\mathrm{SO}_{2}$ by hydroxyl radical $(\mathrm{OH})$. The third one is oxidation of dimethylsulfide (DMS), which is emitted naturally from marine phytoplanktons. The products in the oxidation are $\mathrm{SO}_{2}$ and methanesulfonate (MSA). MSA is also an aerosol but its burden is much smaller than that of sulfate (e.g. Heinzenberg et al., 2000; Prospero et al., 2003). The other sources of $\mathrm{SO}_{2}$ are industrial and human activities through fossil fuel combustion and forest fire through biomass burning. The $\mathrm{SO}_{2}$ in the atmosphere is removed typically within one to three days by oxidation and wet and dry deposition processes (e.g. Seinfeld and Pandis, 1998; Barrie et al., 2001). All formed sulfate is assumed to exist in the particle phase because sulfuric acid has a low vapor pressure (e.g. Seinfeld and Pandis, 1998). Due to the small size and the high hygroscopicity, the wet deposition for sulfate aerosol is a major removal process in the atmosphere compared to the dry deposition (e.g. Rasch et al., 2000).

As suggested in Sect. 1, a difference in the aqueous-phase sulfur chemistry among global aerosol models can be a key to understand a difference in the sulfate simulation. The aqueous-phase sulfur chemistry includes $\mathrm{SO}_{2}$ aqueous-phase oxidations whose treatment is largely different depending on models. The treatment includes a numerical solution in the oxidations, an integrated time resolution in the aqueousphase process, and a value of $\mathrm{pH}$ in the aqueous-phase. To save the amount of CPU time, the most simplified way to treat these processes in the model is to use an approximation in a quasi first-order reaction of the $\mathrm{SO}_{2}$ aqueous-phase oxidations, a same time resolution as that in the transport model, and a fixed $\mathrm{pH}$ value in the calculation (e.g. Takemura et al., 2000). Similar kinds of approximation in the aqueousphase sulfur chemistry and other sulfur processes are adopted by most of global aerosol models (e.g. Textor et al., 2006). Physically based methods (e.g. Feichter et al., 1996; Boucher et al., 2002) set the timestep in the aqueous-phase chemical

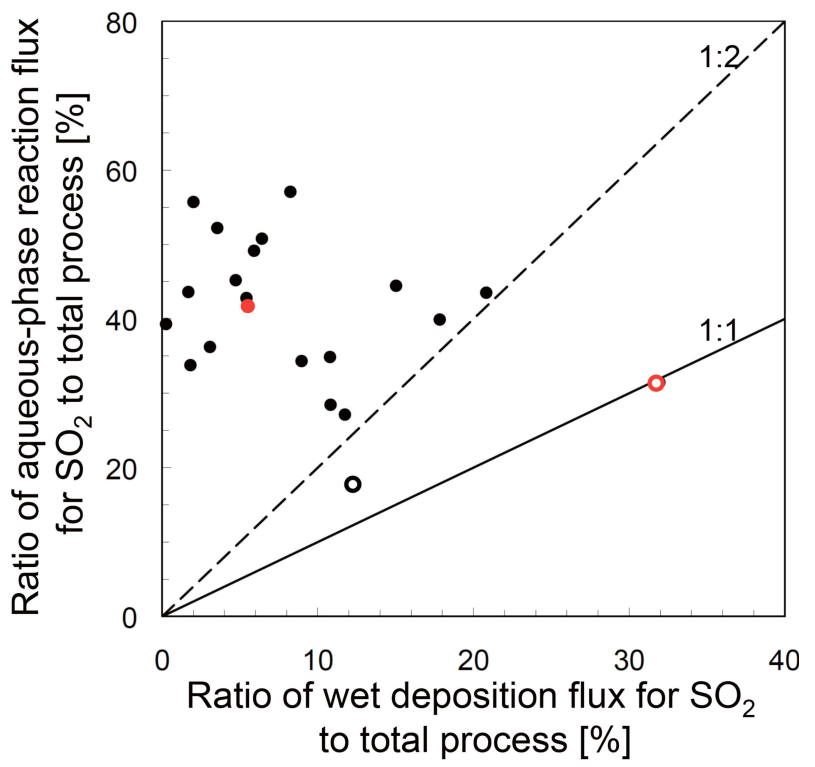

Fig. 2. Correlation of global annual mean $\mathrm{SO}_{2}$ budgets between wet deposition fluxes (x-axis) and aqueous-phase reaction fluxes (yaxis) using model results by various CTM and GCM aerosol models, in ${\mathrm{TgS} \mathrm{yr}^{-1}}^{-1}$. For reference, the 1:1 and 1:2 lines are shown as the solid and dashed lines, respectively. The closed circle in red represents the result in this study using a more physical-based sulfur processes. The open circle in red near the 1:1 line represents the result in Takemura et al. (2000), SPRINTARS, which uses a simplified sulfur process. The open circle in black represents the result in Koch et al. (2006).

reaction to be shorter than that in the transport model, while simplified methods (e.g. Chin et al., 2000; Takemura et al., 2002) set the same time resolution in both the aqueous-phase chemistry and the transport model. For oxidants, i.e. $\mathrm{O}_{3}$, $\mathrm{H}_{2} \mathrm{O}_{2}$, and $\mathrm{OH}$ radical, physically based methods (e.g. Easter et al., 2004; Tie et al., 2005) calculate them with onlinecoupling to chemistry, while simplified methods (e.g. Barth et al., 2000; Koch et al., 2006) use their offline distributions. For dry deposition, physically based methods (e.g. Liu and Penner 2002; Gong et al., 2003) treat all components of the resistance using Zhang et al. (2001), while simplified methods (e.g. Rasch et al., 2000; Pitari et al., 1993, 2002) assume the constant rate of the dry deposition. As shown in Textor et al. (2006), global aerosol models also include an offline calculation of oxidants, i.e. $\mathrm{O}_{3}, \mathrm{H}_{2} \mathrm{O}_{2}$ and $\mathrm{OH}$ radical and a simplified dry deposition of gases and aerosols. Therefore, we show both these simplified and physically-based methods in the following subsections.

\subsection{Treatment of the sulfur aqueous-phase processes}

Two numerical solutions for aqueous-phase sulfur chemistry of global aerosol models are described here. In the approximation in the quasi first-order reaction, a change in the sulfate concentration during time $d t$ is expressed as follows: 
$\frac{d\left[\mathrm{SO}_{4}\right]}{d t}=k\left[\mathrm{SO}_{2}(\mathrm{aq})\right]\left[\mathrm{H}_{2} \mathrm{O}_{2}(\mathrm{aq})\right]$,

where $k$ is the reaction rate, which is set to the same value as Takemura et al. (2000), and terms [ $\left.\mathrm{SO}_{2}(\mathrm{aq})\right]$ and $\left[\mathrm{H}_{2} \mathrm{O}_{2}(\mathrm{aq})\right]$ are aqueous-phase concentrations of $\mathrm{SO}_{2}$ and $\mathrm{H}_{2} \mathrm{O}_{2}$, respectively. In the simplified method, the sulfur system is assumed to be an open system, which means the $\mathrm{H}_{2} \mathrm{O}_{2}$ concentration in the aqueous-phase is always assumed to be constant as

$$
\left[\mathrm{SO}_{4}\right]_{(t+d t)}=\left[\mathrm{SO}_{4}\right]_{(t)}+k\left[\mathrm{SO}_{2}(\mathrm{aq})\right]_{(t)}\left[\mathrm{H}_{2} \mathrm{O}_{2}(\mathrm{aq})\right]_{(t)} d t
$$

where the term of $[A](t)$ means the concentration of a matter $A$ at time $t$. In the case of $\mathrm{SO}_{2}$ oxidation by $\mathrm{O}_{3}$, the expression of the sulfate concentration at time $t$ is also similar to that in the $\mathrm{SO}_{2}$ oxidation by $\mathrm{H}_{2} \mathrm{O}_{2}$.

On the other hand, the sulfur system can be treated more realistically by a closed system, i.e. $\mathrm{H}_{2} \mathrm{O}_{2}$ concentrations in the aqueous-phase are changed by supply from the gas-phase and by loss in the liquid phase. In this system, the sulfate concentration is expressed by an analytical expression of the second-order reaction of $\mathrm{SO}_{2}$ with $\mathrm{H}_{2} \mathrm{O}_{2}$ as follows:

$$
\frac{1}{\left[\mathrm{SO}_{2}(\mathrm{aq})\right]_{(t)}-\left[\mathrm{SO}_{4}\right]_{(t+d t)}}-\frac{1}{\left[\mathrm{SO}_{2}(\mathrm{aq})\right]_{(t)}}=k \cdot d t,
$$

when concentrations of $\mathrm{H}_{2} \mathrm{O}_{2}$ and $\mathrm{SO}_{2}$ are equal to each other. Otherwise, it follows:

$$
\begin{aligned}
& \frac{1}{\left[\mathrm{SO}_{2}(\mathrm{aq})\right]_{(t)}-\left[\mathrm{H}_{2} \mathrm{O}_{2}(\mathrm{aq})\right]_{(t)}} \ln \\
& \left\{\frac{\left[\mathrm{H}_{2} \mathrm{O}_{2}(\mathrm{aq})\right]_{(t)}\left(\left[\mathrm{SO}_{2}(\mathrm{aq})\right]_{(t)}-\left[\mathrm{SO}_{4}\right]_{(t+d t)}\right)}{\left[\mathrm{SO}_{2}(\mathrm{aq})\right]_{(t)}\left(\left[\mathrm{H}_{2} \mathrm{O}_{2}(\mathrm{aq})\right]_{(t)}-\left[\mathrm{SO}_{4}\right]_{(t+d t)}\right)}\right\}=k \cdot d t
\end{aligned}
$$

In the present study we set two sulfur process models, i.e. a simplified model used in the original SPRINTARS model and a more physical-based model with use of Eqs. (3) and (4). We hereafter call these two models original model and improved model.

A resolution for time integration is also critical for the aqueous-phase sulfur chemistry. Soluble gases such as $\mathrm{SO}_{2}$, $\mathrm{H}_{2} \mathrm{O}_{2}$ and $\mathrm{O}_{3}$ in the atmosphere can be partitioned into gas and aqueous phases according to Henry's law. Henry's law equilibrium between gas and aqueous phases occurs typically within one second (Hobbs, 2000). In addition the $\mathrm{SO}_{2}$ in the aqueous phase reacts so rapidly with $\mathrm{H}_{2} \mathrm{O}_{2}$ that the time resolution to integrate the aqueous-phase chemical reaction equations should be finer (e.g. Seinfeld and Pandis, 1998). The timestep, for example, is set to two minutes in Boucher et al. (2002), four minutes in Feichter et al. (1996), ten minutes in Liao et al. (2003), and twenty minutes in Takemura et al. (2000). We thus introduce a sub-cycle calculation by dividing the timestep of general circulation model (GCM), which is typically several tens of minutes, into two minute sub-intervals for solving Eqs. (3) and (4) (see Fig. 3). During the calculation in the sub-cycle, the gas-phase concentrations of $\mathrm{SO}_{2}$ and oxidants are changed only through Henry's law equilibrium. Oxidation of $\mathrm{SO}_{2}$ by $\mathrm{O}_{3}$ is also considered and is calculated just after the oxidation of $\mathrm{SO}_{2}$ by $\mathrm{H}_{2} \mathrm{O}_{2}$. It should be noted that the order of the calculations affects the resulting sulfate concentration and impact on the annually averaged sulfate concentration near the surface and sulfate column burden by $5 \%$ and $10 \%$, respectively.

$\mathrm{A} \mathrm{pH}$ value in the aqueous-phase sulfur chemistry is fixed in the most simplified methods. In the present study the $\mathrm{pH}$ value can be given as,

$\left[\mathrm{H}^{+}\right]=\left[\mathrm{H}_{0}^{+}\right]+f_{1}\left(2\left[\mathrm{SO}_{4}^{2-}\right]+\left[\mathrm{HSO}_{3}^{-}(\mathrm{aq})\right]\right)$,

where $\left[\mathrm{H}^{+}\right],\left[\mathrm{SO}_{4}^{2-}\right]$, and $\left[\mathrm{HSO}_{3}^{-}(\mathrm{aq})\right]$ are hydrogen, sulfate, and sulfurous acid concentrations in the aqueous phase, respectively. In the typical $\mathrm{pH}$ range (4.0-5.6), the sulfurous acid concentration in the aqueous phase is equal to dissolved $\mathrm{SO}_{2}$ concentration in the aqueous phase (e.g. Seinfeld and Pandis, 1998). The term $\left[\mathrm{H}_{0}^{+}\right]$is the hydrogen concentration under the condition of no sulfur components and is estimated to be $10^{-5.6}$. The term $f_{1}$ is a tunable factor set to 0.1 in the present study and the result of global $\mathrm{pH}$ distribution is shown in Fig. S1 in the Supplement. The weak dependence of the $\mathrm{pH}$ on the sulfur components is a better expression than the globally fixed $\mathrm{pH}$, so that our improved method assumes the variable formulation of $\mathrm{pH}$ by Eq. (5).

\subsection{Treatment of oxidants used in the sulfur chemistry}

In global aerosol models, oxidants related to the sulfur chemistry are often prescribed using results from chemical transport models (e.g. Textor et al., 2006). Simulating the aerosol distribution with offline oxidant distribution is very effective to decrease the amount of CPU time, but may increase an error in the sulfate simulation. In this respect, the most important oxidant to be accurately assumed is probably $\mathrm{H}_{2} \mathrm{O}_{2}$ because the $\mathrm{H}_{2} \mathrm{O}_{2}$ can strongly affect the aqueous-phase concentration of $\mathrm{SO}_{2}$ (e.g. Koch et al., 1999). This offline use of $\mathrm{H}_{2} \mathrm{O}_{2}$ produces an overestimation of supply $\mathrm{H}_{2} \mathrm{O}_{2}$ to sulfur oxidations and then an overestimation of sulfate aerosol particularly in wintertime urban areas (e.g. Roelofs et al., 1998). In winter, wet deposition of $\mathrm{H}_{2} \mathrm{O}_{2}$ is known to be the most dominant loss process of $\mathrm{H}_{2} \mathrm{O}_{2}$ because both $\mathrm{OH}$ concentration and actinic radiation are low. Therefore, the wintertime $\mathrm{H}_{2} \mathrm{O}_{2}$ concentration strongly depends on clouds and precipitation. On the other hand, the $\mathrm{H}_{2} \mathrm{O}_{2}$ variability caused by clouds and precipitation is neglected in the simulation using the offline $\mathrm{H}_{2} \mathrm{O}_{2}$ distribution. Furthermore, $\mathrm{H}_{2} \mathrm{O}_{2}$ at low temperature prefers to be in the aqueous phase according to Henry's law. Therefore, using the offline $\mathrm{H}_{2} \mathrm{O}_{2}$ distribution will cause overestimation of the wintertime $\mathrm{H}_{2} \mathrm{O}_{2}$. To eliminate this overestimation in winter, the $\mathrm{H}_{2} \mathrm{O}_{2}$ in the present improved model is treated as a prognostic tracer like in other 
(a) Original SPRINTARS



(b) This study

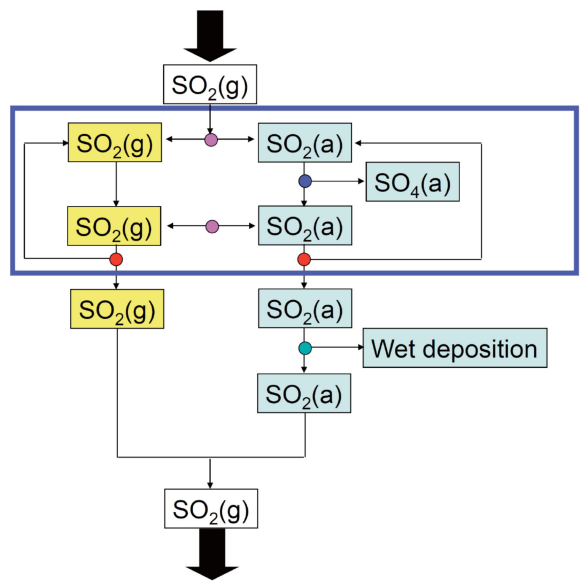

Fig. 3. A flowchart for aqueous-phase reaction of $\mathrm{SO}_{2}$ in (a) the original SPRINTARS and (b) this study. The $\mathrm{SO}_{2}$ in yellow and aqua represent $\mathrm{SO}_{2}$ in the gas-phase and in the aqueous-phase, respectively. The pink, aqua, blue, and red circles correspond to the process of gas-liquid phase equilibrium through Henry's law, wet deposition, sulfate production reaction, and loop for the calculation in a sub-cycle timestep, respectively.

modeling studies (Roelofs et al., 1998; Koch et al., 1999; Barth et al., 2000; Boucher et al., 2002). In the atmosphere, the $\mathrm{H}_{2} \mathrm{O}_{2}$ is produced via hydroperoxyl radical $\left(\mathrm{HO}_{2}\right)$ :

$\mathrm{HO}_{2}+\mathrm{HO}_{2}+M \rightarrow \mathrm{H}_{2} \mathrm{O}_{2}+\mathrm{O}_{2}$,

where $M$ represents a third body, which mainly represents water vapor and nitrogen gas. The $\mathrm{H}_{2} \mathrm{O}_{2}$ is depleted via photo-association:

$\mathrm{H}_{2} \mathrm{O}_{2}+h v \rightarrow \mathrm{OH}+\mathrm{OH}$,

where $h v$ represents a dissociation energy, which is provided by the results from a chemical transport model, CHASER by Sudo et al. (2002), which has been implemented in the MIROC AGCM, every three hour. The $\mathrm{H}_{2} \mathrm{O}_{2}$ is also depleted via $\mathrm{OH}$ :

$\mathrm{H}_{2} \mathrm{O}_{2}+\mathrm{OH} \rightarrow \mathrm{H}_{2} \mathrm{O}+\mathrm{HO}_{2}$.

The reaction rates in Reactions (R1) and (R3) are estimated by Pitts and Pitts (1999). The other loss pathways for the $\mathrm{H}_{2} \mathrm{O}_{2}$ are dry and wet deposition processes and oxidation of $\mathrm{SO}_{2}$ in the aqueous-phase. The contribution of the latter process to the total loss process is so small that it is not considered for $\mathrm{H}_{2} \mathrm{O}_{2}$ cycle in this study.

Other oxidants $\left(\mathrm{O}_{3}\right.$ and $\left.\mathrm{OH}\right)$ are still calculated offline in this study, because their concentrations are relatively less important than those of $\mathrm{H}_{2} \mathrm{O}_{2}$ (e.g. Roelofs et al., 1998) and their predictions are beyond the scope of our study.

\subsection{Dry deposition module for sulfur components}

The dry deposition process is important as a loss process of aerosols and their precursors. Modeling of this process also varies widely among global aerosol models (Textor et al., 2006). Basically, the flux for dry deposition can be expressed as a product of a dry deposition rate and a mass mixing ratio. The dry deposition rate is determined by the following three resistances: (1) aerodynamic resistance, $R_{\mathrm{a}}$, (2) quasi-laminar layer resistance, $R_{\mathrm{b}}$, and (3) surface or canopy resistance, $R_{\mathrm{c}}$ (Seinfeld and Pandis, 1998). For particles, it is written by Seinfeld and Pandis (1998) and Zhang et al. (2001) as follows:

$V_{\mathrm{d}}=\frac{1}{R_{\mathrm{a}}+R_{\mathrm{b}}+R_{\mathrm{a}} R_{\mathrm{b}} V_{\mathrm{s}}}+V_{\mathrm{s}}$

where $V_{\mathrm{s}}$ is the gravitational settling velocity. For gases, it is written by Seinfeld and Pandis (1998) as follows:

$V_{\mathrm{d}}=\frac{1}{R_{\mathrm{a}}+R_{\mathrm{b}}+R_{\mathrm{c}}}$

Generally speaking, the dry deposition process is very effective for gases and coarse particles, whereas it is relatively unimportant for fine particles (Seinfeld and Pandis, 1998). At the same time, the dry deposition for gases is mainly determined by both $R_{\mathrm{a}}$ and $R_{\mathrm{c}}$ and that for fine particles is mainly determined by $R_{\mathrm{b}}$ (Seinfeld and Pandis, 1998). The $R_{\mathrm{b}}$ depends on a surface condition as in Zhang et al. (2001) for sulfate particles and in Wesely (1989) for $\mathrm{SO}_{2}$. Especially the $R_{\mathrm{c}}$ for $\mathrm{SO}_{2}$ can be calculated in principle in the model using the surface condition and the plant variability. Some models, however, ignore the $R_{\mathrm{c}}$ in Eq. (7) to decrease the 
Table 1. Aerosol properties in this model.

\begin{tabular}{llrrr}
\hline Species $^{\mathrm{a}}$ & Distribution & Radius & Standard deviation & Hygroscopicity $^{\mathrm{g}}$ \\
\hline Sulfate & 1-modal $^{\mathrm{b}}$ & $0.0695^{\mathrm{e}}$ & $2.03^{\mathrm{e}}$ & Yes \\
POA & 1-modal $^{\mathrm{b}}$ & $0.1^{\mathrm{e}}$ & $1.80^{\mathrm{e}}$ & Yes \\
BSOA & 1-modal $^{\mathrm{b}}$ & $0.08^{\mathrm{f}}$ & $1.80^{\mathrm{f}}$ & Yes \\
BC & 1-modal $^{\mathrm{b}}$ & $0.0118^{\mathrm{e}}$ & $2.00^{\mathrm{e}}$ & No \\
Soil dust & Bin $^{\mathrm{c}}$ & On-line & On-line & No \\
Sea salt & Bin $^{\mathrm{d}}$ & On-line & On-line & Yes \\
\hline
\end{tabular}

${ }^{a}$ Abbreviations are POA, primary organic aerosol; BSOA, biogenic secondary organic aerosol; BC, Black Carbon; ${ }^{\mathrm{b}}$ assuming a logarithmic normal size distribution; ${ }^{\mathrm{c}} 10$ bins ranging from $0.13 \mu \mathrm{m}$ to $8.2 \mu \mathrm{m}$; ${ }^{\mathrm{d}} 4$ bins ranging from $0.174 \mu \mathrm{m}$ to $5.62 \mu \mathrm{m}$; ${ }^{\mathrm{e}}$ Hess et al. (1998); ${ }^{\mathrm{f}}$ Goto et al. (2008); ${ }^{\mathrm{g}}$ see Table 2 .

Table 2. Hygroscopicity in this model ${ }^{\mathrm{a}}$.

\begin{tabular}{lrrrrrrrr}
\hline RH $(\%)$ & 0 & 50 & 70 & 80 & 90 & 95 & 98 & 99 \\
\hline Sulfate $^{\mathrm{b}}$ & 1 & 1.22 & 1.37 & 1.48 & 1.76 & 2.26 & 2.81 & 3.32 \\
OA $^{\mathrm{c}}$ & 1 & 1.08 & 1.10 & 1.44 & 1.69 & 1.96 & 2.74 & 3.12 \\
Sea salt $^{\mathrm{b}}$ & 1 & 1.07 & 1.28 & 1.99 & 2.38 & 2.88 & 3.77 & 4.69 \\
\hline
\end{tabular}

a Values are aerosol growth factors, defined as the size changes of the particles, as a function of relative humidity (RH).

b The hygroscopicity is set the same in Takemura et al. (2005)

c OA represents organic aerosols including POA and BSOA. The POA and BSOA have the same hygroscopicity as given by Takemura et al. $(2002,2005)$.

amount of CPU time as in the original model in the SPRINTARS model (Takemura et al., 2000). On the other hand, the present improved model use above described dependences using the monthly distributions of $R_{\mathrm{c}}$, which is given by offline calculation of the CHASER model.

\section{Dry deposition module for sulfur components model description for SPRINTARS}

In this study, we use a global three-dimensional aerosol transport-radiation model, Spectral Radiation-Transport Model for Aerosol Species (SPRINTARS), which is described in Takemura et al. (2000, 2002, 2005); we give only a brief description in this paper. The SPRINTARS model has been implemented in an atmospheric GCM developed by the Center for Climate System Research of the University of Tokyo, National Institute for Environmental Studies, and the Frontier Research Center for Global Change (K-1 Developers, 2004; hereafter referred to as MIROC AGCM). The horizontal resolution of the triangular truncation is set to T42 (approximately $2.8^{\circ}$ by $2.8^{\circ}$ in latitude and longitude) and the vertical resolution is set to 20 layers. The time step $d t$ is set to $20 \mathrm{~min}$. The model calculates the mass mixing ratios of the main tropospheric aerosols, i.e. carbonaceous aerosol (BC, POA, i.e. primary organic aerosol and BSOA, i.e. bio- genic secondary organic aerosol), sulfate, soil dust, sea salt, and the precursor gases of sulfate, i.e. $\mathrm{SO}_{2}$ and DMS. The particles are treated as external mixtures for soil dust and sea salt. For carbonaceous aerosols, the BSOA and $50 \% \mathrm{BC}$ mass from fossil fuel source are treated as externally mixed particles, but other carbonaceous particles are treated as internal mixtures of BC and POA. For soil dust and sea salt aerosols, mixing ratios are calculated for various size bins. On the other hand, for POA, BSOA and sulfate aerosols, the dry mode radii are set to $0.1,0.08$ and $0.0695 \mu \mathrm{m}$, respectively (Takemura et al., 2005; Goto et al., 2008). These parameters and others are listed in Tables 1 and 2 .

The emission inventories for 2000 for aerosols, with their precursors and oxidants, except for a precursor of BSOA and $\mathrm{SO}_{2}$ are those described by Takemura et al. (2005). The precursor gas of BSOA is assumed to be biogenic monoterpene $\left(\mathrm{C}_{10} \mathrm{H}_{16}\right)$, which is obtained from the Global Emissions Inventory Activity (GEIA) database (Guenther et al., 1995), and its diurnal emission variation is calculated using temperature dependences. The anthropogenic $\mathrm{SO}_{2}$ emission flux in 2000 used in this study is interpolated from: the EMEP emission inventory (http://webdab.emep.int/) over Europe, Streets et al. (2003) over Asia, and Takemura et al. (2005) in other regions. For comparison with the AEROCOM results, we also use the $\mathrm{SO}_{2}$ emission inventory by Dentener et al. (2006). The $\mathrm{SO}_{2}$ emission from continuous volcanic eruptions is based on the GEIA database and the $\mathrm{SO}_{2}$ emission from biomass burning is based on the GEIA database and Spiro et al. (1992). The DMS emission flux is calculated using an empirical relation reported by Bates et al. (1987) as in Takemura et al. (2002) and Sudo et al. (2002). To predict the $\mathrm{H}_{2} \mathrm{O}_{2}$ mixing ratio in our improved method, offline data for three-hour averaged $\mathrm{HO}_{2}$ and $h v$ are calculated by a chemical transport model, CHASER (Sudo et al., 2002). Other oxidants $\left(\mathrm{O}_{3}\right.$ and $\left.\mathrm{OH}\right)$ distributions are also derived from the CHASER model.

The aerosol transport processes include emission, advection, diffusion, sulfur chemistry, wet deposition and gravitational settling. The radiation scheme, MSTRN-8, in the MIROC AGCM can handle scattering, absorption, and 




- quasi 1st-order reaction -2 nd-order reaction

Fig. 4. An example of predicted sulfate concentrations through the $\mathrm{SO}_{2}$ aqueous-phase oxidation during twenty minutes for the conditions of $300 \mathrm{~K}$ and 5 ppbv $\mathrm{H}_{2} \mathrm{O}_{2}$. The $\mathrm{x}$-axis values are initial $\mathrm{SO}_{2}$ concentrations and the $\mathrm{y}$-axis values are sulfate concentration formed from $\mathrm{SO}_{2}$ oxidation by $\mathrm{H}_{2} \mathrm{O}_{2}$.

emission by aerosol and cloud particles, as well as absorption by gaseous constituents and can calculate the aerosol direct effect (Nakajima et al., 2000). The aerosol direct radiative forcing due to anthropogenic aerosols is calculated as the difference in net fluxes with and without anthropogenic aerosols under the same meteorological conditions by the method of Takemura et al. (2005) and Goto et al. (2008). Although the model can calculate the radiative forcing under the clear-sky and the all-sky conditions at any vertical levels, in this paper we show only the results under the all-sky conditions at the top of atmosphere (TOA) to discuss the sensitivity of the radiative forcing among different methods. For calculation of the aerosol indirect effect, we diagnose cloud droplet number concentration, liquid water content (LWC), and cloud droplet effective radius as described elsewhere (Suzuki et al., 2004; Takemura et al., 2005; Goto et al., 2008).

All experiments use the monthly-averaged global distributions for sea surface temperature and sea ice are provided by the Hadley Centre, UK Met Office (Rayner et al., 2003). For proper simulations of the aerosol distribution, all experiments are conducted with nudged meteorological fields (wind, water vapor, and temperature) every six-hour. The data are reanalysis data provided by the NCAR/NCEP. All experiments, except for experiments for comparison of simulated aerosol mass concentrations with aircraft and ship observations, are run for two years (1 January 2002-31 December 2003) after using the first year for spin up.

\section{Sulfate simulation with original and improved methods}

In this section, we investigate differences in sulfate simulation between original and improved methods of treating sul- fur chemistry. The results are studied in order to evaluate the effect of following five elements: (1) method of the solution for the aqueous-phase sulfur chemistry, (2) timestep to solve the aqueous-phase sulfur chemistry, (3) $\mathrm{pH}$ calculation in the aqueous-phase, (4) treatment of $\mathrm{H}_{2} \mathrm{O}_{2}$ as a prognostic variable, and (5) dry deposition process of sulfur components.

\subsection{Method of solving the aqueous-phase sulfur chemistry}

As explained in Sect. 2, the original method calculates sulfate formation by a solution of a quasi first-order reaction, that means the $\mathrm{H}_{2} \mathrm{O}_{2}$ concentration in the aqueous-phase is prescribed and fixed at the initial concentration. However, this assumption cannot be applicable in the case of high $\mathrm{SO}_{2}$ concentration because of large consumptions of $\mathrm{H}_{2} \mathrm{O}_{2}$ through the $\mathrm{SO}_{2}$ oxidation. In order to properly predict sulfate concentration, therefore, the formation of sulfate through the aqueous-phase sulfur chemistry should be calculated by solving a second-order reaction with variable $\mathrm{H}_{2} \mathrm{O}_{2}$ concentrations in the aqueous-phase. In this study, Eqs. (3) and (4) with a sub-cycle timestep of $120 \mathrm{~s}$ are used to calculate the sulfate concentration.

When the $\mathrm{SO}_{2}$ concentration is high, we find clear differences in the calculated sulfate concentrations between the quasi first-order reaction and the second-order reaction (Fig. 4). In case of high $\mathrm{SO}_{2}$ concentrations, the calculated sulfate concentrations by the second-order reaction are lower than those by the quasi first-order reaction. The overestimation of the sulfate concentration by the first-order reaction is caused by the assumption of the open system that allows excess supply of $\mathrm{H}_{2} \mathrm{O}_{2}$ from the gas-phase to the aqueousphase. Actually, both the saturation of the sulfate production and the reduction of $\mathrm{H}_{2} \mathrm{O}_{2}$ by $\mathrm{SO}_{2}$ oxidation often occur in the real atmosphere over urban areas. In case of low $\mathrm{SO}_{2}$ concentrations, i.e. above boundary layers and/or over remote areas, on the other hand, the calculated sulfate concentrations by the second-order reaction are higher than those by the quasi first-order reaction (Fig. 4). This is because consumed $\mathrm{H}_{2} \mathrm{O}_{2}$ concentrations by the $\mathrm{SO}_{2}$ oxidation in the aqueous-phase are larger than supplied $\mathrm{H}_{2} \mathrm{O}_{2}$ concentrations through Henry's law equilibrium before the step of the $\mathrm{SO}_{2}$ oxidation. Therefore, the sulfate concentration by the quasi first-order reaction is underestimated compared to that by the second-order reaction.

In this sensitivity analysis we use a relative bias (RB), defined as $\mathrm{RB}=(S-C) / C$, where $S$ and $C$ represent results simulated by the simplified and the improved methods, respectively. In the present experiments, $S$ represents simulated sulfate concentration with the solution in the quasi firstorder reaction (hereafter referred to as quasi first-order solution or Q1ST), or with the second-order solution with large timestep of $d t=1200 \mathrm{~s}$ (referred to as coarse second-order solution or $\mathrm{C} 2 \mathrm{ND}$ ), while $\mathrm{C}$ represents the simulated value with the analytical solution in the second-order reaction with 
Table 3. Experimental designs of comparison using original and improved methods.

\begin{tabular}{|c|c|c|c|c|c|}
\hline $\begin{array}{l}\text { Name of } \\
\text { experiments }\end{array}$ & $\begin{array}{l}\text { Solution in } \\
\text { aqueous-phase } \\
\text { reactions }\end{array}$ & $\begin{array}{l}\text { Timestep in } \\
\text { aqueous-phase } \\
\text { reactions }\end{array}$ & $\begin{array}{l}\text { Treatment of } \\
\text { pH in } \\
\text { aqueous-phase }\end{array}$ & $\begin{array}{l}\text { Treatment of } \\
\mathrm{H}_{2} \mathrm{O}_{2} \text { in the } \\
\text { simulation }\end{array}$ & $\begin{array}{l}\text { Dry } \\
\text { Deposition }\end{array}$ \\
\hline \multicolumn{6}{|c|}{ Standard experiment } \\
\hline CTL & 2nd-order & $d t=120 \mathrm{~s}$ & Eq. (5) & Online & This study \\
\hline \multicolumn{6}{|c|}{ Solution in aqueous-phase } \\
\hline Q1ST & Quasi 1st-order & $d t=1200 \mathrm{~s}$ & Eq. (5) & Online & This study \\
\hline $\mathrm{C} 2 \mathrm{ND}$ & 2nd-order & $d t=1200 \mathrm{~s}$ & Eq. (5) & Online & This study \\
\hline \multicolumn{6}{|c|}{ Timestep in sulfur chemistry } \\
\hline DT60 & 2nd-order & $d t=60 \mathrm{~s}$ & Eq. (5) & Online & This study \\
\hline DT240 & 2nd-order & $d t=240 \mathrm{~s}$ & Eq. (5) & Online & This study \\
\hline DT600 & 2nd-order & $d t=600 \mathrm{~s}$ & Eq. (5) & Online & This study \\
\hline DT1200 & 2nd-order & $d t=1200 \mathrm{~s}$ & Eq. (5) & Online & This study \\
\hline \multicolumn{6}{|c|}{$\mathrm{pH}$ calculation } \\
\hline PH4.5 & 2nd-order & $d t=120 \mathrm{~s}$ & $\mathrm{pH}=4.5$ (fixed) & Online & This study \\
\hline PH5.6 & 2nd-order & $d t=120 \mathrm{~s}$ & $\mathrm{pH}=5.6$ (fixed) & Online & This study \\
\hline PHF96 & 2nd-order & $d t=120 \mathrm{~s}$ & $\begin{array}{l}\text { pH used in } \\
\text { Feichter et al. (1996) }\end{array}$ & Online & This study \\
\hline \multicolumn{6}{|c|}{ Treatment of $\mathrm{H}_{2} \mathrm{O}_{2}$} \\
\hline $\mathrm{H}_{2} \mathrm{O}_{2}$ & 2nd-order & $d t=120 \mathrm{~s}$ & Eq. (5) & Offline & This study \\
\hline \multicolumn{6}{|c|}{ Dry deposition for sulfur species } \\
\hline DRYDP & 2nd-order & $d t=120 \mathrm{~s}$ & Eq. (5) & Online & Original \\
\hline
\end{tabular}

$d t=120 \mathrm{~s}$ (referred to as fine second-order solution or CTL). The summaries of the experimental conditions and the results are described in Tables 3 and 4, respectively. Among the results of Q1ST, the largest value of the annually averaged RB of the sulfate concentrations near the surface is shown over the polluted areas with ranges of $+100.7 \%$ to $+165.7 \%$, as shown in Table 4. These values are much larger than those in the results of $\mathrm{C} 2 \mathrm{ND}$, because of the assumption of excess supply of $\mathrm{H}_{2} \mathrm{O}_{2}$ in the aqueous-phase as shown in Fig. 4. For the sulfate column burden, on the other hand, the annually averaged RBs are estimated to be minus almost over the world with the global mean value of $-26.3 \%$ in Q1ST and $-11.9 \%$ in C2ND, respectively, because of underestimated sulfate concentrations at upper heights (above boundary layers) caused by a lack of $\mathrm{H}_{2} \mathrm{O}_{2}$ in the aqueous-phase in Q1ST as shown in Fig. 4. As a conclusion, the method with Q1ST largely overestimates the predicted sulfate concentration near the surface and the differences in the sulfate concentration between Q1ST and C2ND are much larger than those between C2ND and CTL. At the same time, the substitution of the quasi first-order solution by the second-order reaction increases the sulfate column burden all over the world except China. As mentioned later, this difference in the simulated sulfate column burden is the largest among all modifications of the sulfur processes in this study.

\subsection{Timestep to solve the aqueous-phase sulfur chemistry}

The timestep to solve the $\mathrm{SO}_{2}$ oxidation process in the aqueous-phase is also critical to determine the accurate sulfate production. Theoretically, the timestep $d t$ in Eqs. (3) and (4) is required to be very short because both the oxidation rate of $\mathrm{SO}_{2}$ by $\mathrm{H}_{2} \mathrm{O}_{2}$ and the rate of Henry's law equilibrium are very fast (e.g. Seinfeld and Pandis, 1998). On the other hand, the timestep in the model is limited by resulting computer burdens of the GCM calculation. Therefore, the sensitivity tests for different timesteps are required to determine the optimized ones for fast yet accurate simulation. The smallest timestep among GCMs is two minutes, so that the standard experiment in this study sets to two minutes $(d t=120 \mathrm{~s})$. For the sensitivity experiments, timesteps are set to $d t=600 \mathrm{~s}, 240 \mathrm{~s}, 60 \mathrm{~s}$, and $30 \mathrm{~s}$. These values in the sensitivity experiments are used in the sulfur chemistry in other global aerosol models (e.g. Feichter et al., 1996; Boucher et al., 2002). 
Table 4. Annual mean relative bias $(\mathrm{RB})$, defined as $\mathrm{RB}=(S-C) / C$ where $S$ and $C$ represent results simulated by the simplified and improved methods: (a) sulfate surface concentrations and (b) sulfate column burdens. The simplified methods are different in each experiment whose abbreviations are described in Table 3. The improved method corresponds to the experiment named as CTL in Table 3.

\begin{tabular}{|c|c|c|c|c|c|c|c|c|c|}
\hline \multicolumn{10}{|c|}{ (a) Surface concentration in units of percentage } \\
\hline \multirow[t]{2}{*}{ Experiments } & \multicolumn{9}{|c|}{ Regions* } \\
\hline & GL & $\mathrm{NH}$ & $\mathrm{SH}$ & USA & EU & $\mathrm{CN}$ & IN & NP & $\mathrm{CP}$ \\
\hline & \multicolumn{9}{|c|}{ Solution in aqueous-phase } \\
\hline Q1ST & 70.7 & 82.5 & 33.0 & 100.7 & 150.2 & 165.7 & 105.0 & 83.4 & 44.6 \\
\hline \multirow[t]{2}{*}{$\mathrm{C} 2 \mathrm{ND}$} & -16.9 & -15.6 & -21.0 & -17.8 & -12.5 & -17.7 & -9.1 & -12.6 & -26.4 \\
\hline & \multicolumn{9}{|c|}{ Timestep in sulfur chemistry } \\
\hline DT60 & 2.0 & 1.7 & 2.9 & 1.8 & 0.9 & 1.3 & 1.8 & 1.5 & 4.3 \\
\hline DT240 & -2.4 & -2.0 & -3.7 & -2.0 & -1.0 & -1.4 & -1.2 & -1.8 & -5.6 \\
\hline DT600 & -6.8 & -5.7 & -10.2 & -5.3 & -2.5 & -3.8 & -3.9 & -7.2 & -15.4 \\
\hline \multirow[t]{2}{*}{ DT1200 } & -11.2 & -9.5 & -16.7 & -8.8 & -4.3 & -6.7 & -6.3 & -11.6 & -24.6 \\
\hline & \multicolumn{9}{|c|}{$\mathrm{pH}$ calculation } \\
\hline PH4.5 & -6.4 & -5.1 & -10.7 & -4.0 & -1.8 & -2.3 & -3.5 & -5.2 & -17.0 \\
\hline PH5.6 & 1.5 & 1.5 & 1.8 & 3.1 & 1.5 & 3.1 & 2.3 & -3.6 & 0.9 \\
\hline \multirow[t]{2}{*}{ PHF96 } & -1.7 & -1.7 & -1.6 & -2.9 & -0.9 & -2.6 & -1.8 & 2.0 & 0.0 \\
\hline & \multicolumn{9}{|c|}{ Treatment of $\mathrm{H}_{2} \mathrm{O}_{2}$} \\
\hline \multirow[t]{2}{*}{$\mathrm{H}_{2} \mathrm{O}_{2}$} & 6.5 & 7.7 & 2.5 & 17.3 & 17.1 & 18.1 & 1.7 & 1.6 & 0.1 \\
\hline & \multicolumn{9}{|c|}{ Dry deposition for sulfur species } \\
\hline DRYDP & -12.0 & -12.5 & -10.3 & -10.6 & -11.1 & -5.3 & -15.2 & -16.7 & -8.3 \\
\hline
\end{tabular}

Firstly, we conduct sensitivity experiments using a box model to calculate the aqueous-phase sulfur chemistry. In polluted areas where concentrations exceed 1 ppbv for $\mathrm{SO}_{2}$, 3 ppbv for $\mathrm{H}_{2} \mathrm{O}_{2}$, and 30 ppbv for $\mathrm{O}_{3}$ concentrations, the $\mathrm{RB}$ values are estimated to be $-47 \%(d t=600 \mathrm{~s}),-14 \%(240 \mathrm{~s})$, $+3 \%(60 \mathrm{~s})$, and $+3 \%(30 \mathrm{~s})$, respectively. The results indicate that longer timesteps decrease predicted sulfate formations due to insufficient supply of gases, especially $\mathrm{SO}_{2}$, from the gas-phase through Henry's law equilibrium. And the results also show that the timestep is enough to be equal to or less than $120 \mathrm{~s}$. Secondly, we calculate global sulfate concentrations with various timesteps as shown in Table 4 under the experimental condition described in Table 3. Difference in the column burdens of simulated sulfate between experiments with the different timesteps is caused by differences in sulfate production rates under lower $\mathrm{SO}_{2}$ concentrations, as suggested in the previous subsection. In the simulation with $d t=240 \mathrm{~s}$ (DT240 in Tables 3 and 4), the annually and globally averaged RB value of the sulfate concentration near the surface is estimated to be less than $5 \%$. The magnitude of the RB is smaller than that obtained by the box model calculation, because the aqueous-phase reaction occurs only in a cloudy area in the global calculation. The additional computer burden caused by using $120 \mathrm{~s}$ instead of $240 \mathrm{~s}$ is es- timated to be less than $1 \%$. Therefore, the timestep of $120 \mathrm{~s}$ is applicable in the global aerosol model and hence it is used in our improved model.

\section{3 $\mathrm{pH}$ calculation in the aqueous phase}

The $\mathrm{pH}$ in the aqueous phase is also critical to determine not only the reaction rate in the $\mathrm{SO}_{2}$ aqueous-phase oxidation but also Henry's law equilibrium of the gases. At the same time, dissolved ions into aqueous phase through Henry's law determine the $\mathrm{pH}$ value. Therefore, the $\mathrm{pH}$ is an important variable that should be monitored to properly solve the $\mathrm{SO}_{2}$ aqueous-phase oxidation. In most global aerosol models including the original SPRINTARS, the $\mathrm{pH}$ values are fixed and set to be 4.5 (Koch et al., 1999; Adams et al., 1999; Park et al., 2004; Easter et al., 2004; Liu et al., 2005) or 5.6 (Takemura et al., 2000). In polluted areas, for example, an acidity in the aqueous-phase is determined by a balance between cations and anions; therefore the $\mathrm{pH}$ value over polluted areas is lower than that over remote oceans due to abundance of sulfate. In order to calculate the change in $\mathrm{pH}$, the $\mathrm{pH}$ value in this study is calculated online depending on several ion concentrations as in other studies (Feichter et al., 1996; Boucher et al., 2002; Sudo et al., 2002; Liao et al., 
Table 4. Continued.

(b) Column burdens in units of percentage

\begin{tabular}{|c|c|c|c|c|c|c|c|c|c|}
\hline \multirow[t]{2}{*}{ Experiments } & \multicolumn{9}{|c|}{ Regions* } \\
\hline & GL & NH & $\mathrm{SH}$ & USA & $\mathrm{EU}$ & $\mathrm{CN}$ & IN & NP & $\mathrm{CP}$ \\
\hline & \multicolumn{9}{|c|}{ Solution in aqueous-phase } \\
\hline Q1ST & -26.3 & -18.1 & -46.6 & -4.3 & -8.7 & 37.4 & 3.3 & -26.7 & -57.7 \\
\hline \multirow[t]{2}{*}{$\mathrm{C} 2 \mathrm{ND}$} & -11.9 & -11.1 & -13.9 & -13.9 & -11.3 & -17.6 & -8.6 & -7.3 & -15.2 \\
\hline & \multicolumn{9}{|c|}{ Timestep in sulfur chemistry } \\
\hline DT60 & 1.4 & 1.2 & 1.8 & 1.6 & 0.9 & 1.5 & 1.4 & 0.6 & 2.3 \\
\hline DT240 & -1.7 & -1.4 & -2.3 & -1.8 & -1.2 & -1.6 & -1.3 & -0.7 & -2.8 \\
\hline DT600 & -4.6 & -4.0 & -6.2 & -4.8 & -3.2 & -4.4 & -3.5 & -2.9 & -7.7 \\
\hline \multirow[t]{2}{*}{ DT1200 } & -7.7 & -6.6 & -10.4 & -7.8 & -5.4 & -7.4 & -5.7 & -4.2 & -12.5 \\
\hline & \multicolumn{9}{|c|}{$\mathrm{pH}$ calculation } \\
\hline PH4.5 & -3.7 & -2.9 & -5.8 & -3.7 & -2.3 & -2.0 & -3.0 & -0.5 & -7.5 \\
\hline PH5.6 & 1.2 & 1.0 & 1.5 & 2.6 & 1.7 & 2.7 & 2.0 & -1.7 & 1.1 \\
\hline \multirow[t]{2}{*}{ PHF96 } & -1.3 & -1.2 & -1.5 & -2.4 & -1.4 & -2.6 & -1.8 & 0.5 & -0.9 \\
\hline & \multicolumn{9}{|c|}{ Treatment of $\mathrm{H}_{2} \mathrm{O}_{2}$} \\
\hline \multirow[t]{2}{*}{$\mathrm{H}_{2} \mathrm{O}_{2}$} & 2.5 & 2.9 & 1.4 & 6.2 & 7.7 & 14.4 & 0.6 & 1.3 & 1.0 \\
\hline & \multicolumn{9}{|c|}{ Dry deposition for sulfur species } \\
\hline DRYDP & -11.9 & -13.0 & -9.0 & -12.1 & -11.4 & -8.5 & -16.1 & -14.1 & -6.8 \\
\hline
\end{tabular}

${ }^{*}$ Abbreviations are GL, globe $\left(0^{\circ}-360^{\circ} \mathrm{E}, 90^{\circ} \mathrm{S}-90^{\circ} \mathrm{N}\right)$; NH, Northern Hemisphere $\left(0^{\circ}-360^{\circ} \mathrm{E}, 0^{\circ}-90^{\circ} \mathrm{N}\right)$; $\mathrm{SH}, \mathrm{Southern} \mathrm{Hemisphere}\left(0^{\circ}-360^{\circ} \mathrm{E}, 0^{\circ}-90^{\circ} \mathrm{S}\right)$; USA, the United of States $\left(100^{\circ} \mathrm{W}-60^{\circ} \mathrm{W}, 30^{\circ} \mathrm{N}-45^{\circ} \mathrm{N}\right)$; EU, Europe $\left(10^{\circ} \mathrm{E}-25^{\circ} \mathrm{E}, 45^{\circ} \mathrm{N}-55^{\circ} \mathrm{N}\right)$; CN, China $\left(110^{\circ} \mathrm{E}-125^{\circ} \mathrm{E}, 25^{\circ} \mathrm{N}-45^{\circ} \mathrm{N}\right) ; \mathrm{IN}, \mathrm{India}\left(65^{\circ} \mathrm{E}-90^{\circ} \mathrm{E}, 10^{\circ} \mathrm{N}-25^{\circ} \mathrm{N}\right)$; NP, northern Pacific ocean $\left(150^{\circ} \mathrm{W}-150^{\circ} \mathrm{E}, 30^{\circ} \mathrm{N}-45^{\circ} \mathrm{N}\right)$; CP, central Pacific ocean $\left(150^{\circ} \mathrm{W}-90^{\circ} \mathrm{W}, 30^{\circ} \mathrm{S}-10^{\circ} \mathrm{S}\right)$.

2003). The ion components considered are different from each model, so that the expression for the $\mathrm{pH}$ is different. In the improved method of this study, we calculate the $\mathrm{pH}$ value using Eq. (5) as shown in Sect. 2. The annually averaged pH value in low-level clouds is lowest in polluted areas with a range of 4.2-5.0 and highest in remote oceans with a range of 5.4-5.6, as also shown in Fig. S1 in the Supplement.

Next, sensitivity tests are performed by giving two different $\mathrm{pH}$ prescriptions at 4.5 and 5.6. We calculate the RB using the result with Eq. (5) as CTL. The annually averaged RB values of global sulfate concentrations near the surface are estimated to be $-6.4 \%$ (pH 4.5) and $+1.5 \%$ (pH 5.6), respectively, as shown in Table 4 . The signs of the RB values are reasonable because a decrease in the $\mathrm{pH}$ causes a decrease in the sulfate production (e.g. Seinfeld and Pandis, 1998). The magnitude of the RB on a global scale is almost the same as that in the polluted areas. In the north Pacific polluted by anthropogenic aerosols from East Asia, the annually averaged RB values of surface sulfate concentrations are estimated to be $-5.2 \%(\mathrm{pH} 4.5)$ and $-3.6 \%$ (pH 5.6), respectively. These results indicate that a slight decrease in the $\mathrm{pH}$ from 5.6 to 4.5 causes a slight decrease in the sulfate concentration everywhere and use of the variable $\mathrm{pH}$ will cause a decrease in the sulfate concentration in polluted areas and an increase in the sulfate concentration in outflow areas. The changes in the simulated sulfate concentrations over polluted and outflow areas bring results slightly closer to the observed values compared to those with the fixed $\mathrm{pH}$ method in the original SPRINTARS, which overestimates the sulfate column burdens over polluted areas and underestimates them over outflow areas as reported by Takemura et al. (2000). Furthermore, another sensitivity experiment is carried out using the variable $\mathrm{pH}$ method of Feichter et al. (1996), which assumes the relation $\left[\mathrm{H}^{+}\right]=\left[\mathrm{SO}_{4}^{2-}\right]+\left[\mathrm{HSO}_{3}^{-}\right]$, as shown in results of PHF96 in Table 4. Differences in the simulated sulfate concentrations both at the surface and in the column all over the world between PHF96 and CTL are less than $3 \%$. In summary, the results with the variable $\mathrm{pH}$ expression, Eq. (5) in this study, are slightly better than those with the fixed $\mathrm{pH}$ of 5.6 and the additional computer burdens for the $\mathrm{pH}$ calculation are negligible, so the variable $\mathrm{pH}$ method with Eq. (5) can be applicable in the global aerosol model.

\subsection{Treatment of $\mathrm{H}_{2} \mathrm{O}_{2}$ as a prognostic variable}

$\mathrm{H}_{2} \mathrm{O}_{2}$ is also a critical composition to oxidize $\mathrm{SO}_{2}$ in the aqueous-phase to provide sulfate in the atmosphere. In GCM run with the SPRINTARS model, the $\mathrm{H}_{2} \mathrm{O}_{2}$ distribution is provided offline from an independent GCM run with the CHASER model. This offline use of $\mathrm{H}_{2} \mathrm{O}_{2}$ distribution 
causes unrealistic variability in the wintertime $\mathrm{H}_{2} \mathrm{O}_{2}$ near urban areas due to abundant $\mathrm{H}_{2} \mathrm{O}_{2}$ (e.g. Koch et al., 1999). To eliminate this problem, the improved method of this study treats $\mathrm{H}_{2} \mathrm{O}_{2}$ as a prognostic tracer as in several other models (Roelofs et al., 1998; Koch et al., 1999; Barth et al., 2000; Boucher et al., 2002).

For evaluating the method of offline $\mathrm{H}_{2} \mathrm{O}_{2}$ distribution, we calculate the RB between results with online and offline $\mathrm{H}_{2} \mathrm{O}_{2}$ distributions. As suggested by the previous studies such as Barth et al. (2000), the RB values using the result with online $\mathrm{H}_{2} \mathrm{O}_{2}$ distribution as CTL are generally positive as shown in Table 4, because of excess $\mathrm{H}_{2} \mathrm{O}_{2}$ especially in winter. In Europe, for example, the RB of the sulfate concentration near the surface is estimated to be $+17.1 \%$. As a result, the simulated sulfate concentrations using the online $\mathrm{H}_{2} \mathrm{O}_{2}$ distribution are underestimated near the surface as compared to observations, as also reported by other model studies (e.g. Roelofs et al., 1998). The reason is probably that additional oxidants or additional oxidation processes are needed to be implemented or that precipitation and cloud distributions in the simulation are not well represented (Roelofs et al., 1998; Boucher et al., 2002). In summary, even though inclusion of the prognostic $\mathrm{H}_{2} \mathrm{O}_{2}$ tracer method does not always give better results for sulfate distribution, its treatment in the present study is more realistic than that in the simplified method.

\subsection{Dry deposition process of sulfur components}

The dry deposition process in global aerosol models is important especially for accurate simulation of gas and coarse particle distributions. Basically, the dry deposition rate for gases is determined by three factors, i.e. aerodynamic resistance $R_{\mathrm{a}}$, quasi-laminar layer resistance $R_{\mathrm{b}}$, and canopy resistance $R_{\mathrm{c}}$ defined in Sect. 2.3, but the original SPRINTARS ignores the dependence of the dry deposition rate on term $R_{\mathrm{c}}$, which can be critical for atmospheric sulfur cycle, especially for $\mathrm{SO}_{2}$ (e.g. Seinfeld and Pandis, 1998). To evaluate this approximation, we first introduce these three factors as Eqs. (6) and (7) in the dry deposition process of the present improved method.

We study the impact of $\mathrm{SO}_{2}$ dry deposition using the improved method (as CTL) and the original method of SPRINTARS on the sulfate simulation. Table 4 shows that annually globally averaged $\mathrm{RB}$ values of surface sulfate and $\mathrm{SO}_{2}$ concentrations and sulfate column burden are calculated to be $-12.0 \%$ and $-11.9 \%$, respectively. In other areas, their values are estimated to be at most $-20 \%$. For $\mathrm{SO}_{2}$, annually globally averaged RB values of surface concentrations and column burden are calculated as $-28.3 \%$ and $-24.4 \%$, respectively. In other areas, their values are estimated to be ranging from $-30 \%$ to $-10 \%$. For gases, $R_{\mathrm{c}}$ has a great impact on the dry deposition rate. Therefore, ignoring the term $R_{\mathrm{c}}$ for $\mathrm{SO}_{2}$ mainly causes an overestimation of dry deposition rate for $\mathrm{SO}_{2}$, and thus we found decreases in the sul- fate and $\mathrm{SO}_{2}$ concentrations. In conclusion, we find that differences in the dry deposition modeling also have relatively large impacts on the sulfur budget compared to differences in other parts of the sulfur process.

\section{Comparison of simulated global sulfate distributions with observation}

In this section, we compare simulated sulfate distributions calculated by simplified and improved methods with observed values. The simplified methods mentioned above are adapted into the original SPRINTARS model (Takemura et al., 2005), so that hereafter we call the model OS. We also adapted the improved methods into the SPRINTARS model, and hereafter called NS. That means all five elements to investigate impacts of the sulfate prediction in the previous Sect. are considered in the NS calculation.

\subsection{Industrial areas}

Figure 5 firstly shows results over North America, Europe, and East Asia, which include the largest industrial areas in the world and have many measurement sites over North America by IMPROVE (http://vista.cira.colosate.edu/ IMPROVE/), over Europe by EMEP (http://tarantula.nilu.no/ projects/ccc/emepdata.html), and over East Asia by EANET (http://www.eanet.cc/product.html). The improved method of solving the $\mathrm{SO}_{2}$ aqueous-phase oxidation in NS gives a lower sulfate concentration near the surface and higher sulfate column burden compared to the simplified model in OS, mainly because of the difference in the solution of the aqueous-phase sulfur chemistry as mentioned in Sect. 4. Figure 5 indicates that over three industrial areas the simulated sulfate concentrations in OS are overestimated compared to the observation values, whereas those values in NS are much comparable to the observation values. Over North America, for example, the simulation/observation ratios in OS and NS are 1.65 and 0.88 , respectively. The correlation coefficient in NS is calculated to be 0.86 , whereas that ranges $0.62-0.95$ reported by previous studies (Park et al., 2004; Stier et al., 2005; Koch et al., 2006; Chin et al., 2007). Over East Asia, it should be noted that the monitoring sites of sulfate in the EANET observation network here are not available in China where the simulated sulfate concentrations in OS are likely to be much higher than those in the regional model simulations as suggested by a model intercomparison project (Hollway et al., 2008; Fig. S2 in the Supplement). In conclusion, the results in NS are much better than those in OS. The improvement of the surface sulfate concentration in NS probably is attributed to the suppression in the sulfate production rate under higher $\mathrm{SO}_{2}$ concentrations, which is supported by the previous sensitivity tests.

Secondly, Fig. 6 shows comparisons between simulated and observed vertical profiles of sulfate mixing ratios. The 
(a) North America



(b) Europe

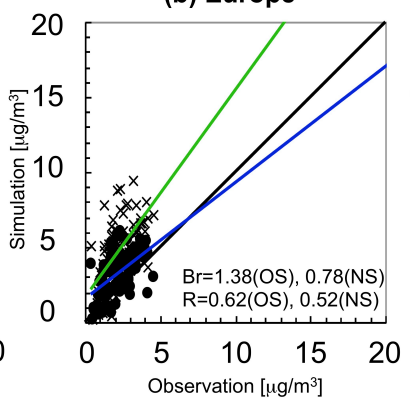

(c) East Asia



Fig. 5. Simulated and observed monthly mean surface mass concentrations of sulfate over (a) North America, (b) Europe and (c) East Asia. The black line represents 1:1 line between observations and the simulations. The blue and green lines represent linear regressions of the simulations in NS and OS, respectively. The $B_{\mathrm{r}}$ and $R^{2}$ values in the figure represent a relative bias, defined as a ratio of simulation to observation, and a correlation coefficient, respectively. The $\mathrm{x}$-axis values are month and the $\mathrm{y}$-axis values are sulfate mass concentrations in $\mu \mathrm{g} \mathrm{m}^{-3}$.

(a) INTEX-A

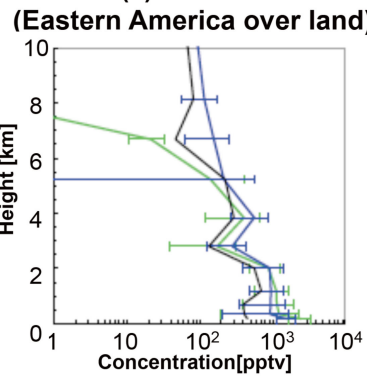

(b) INTEX-A

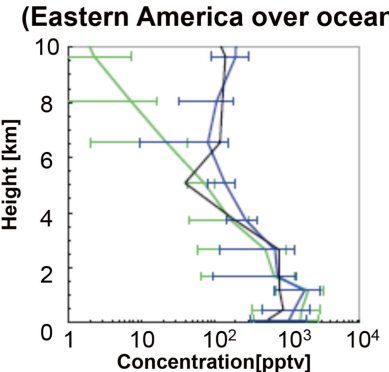

(c) INTEX-B

(Mexico)

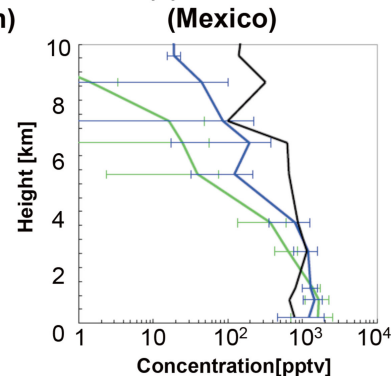

(d) TRACE-P

$\left(115^{\circ} \mathrm{E}-150^{\circ} \mathrm{E}, 10^{\circ} \mathrm{N}-25^{\circ} \mathrm{N}\right)$

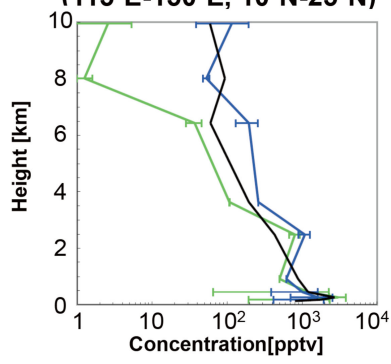

(e) TRACE-P

$\left(115^{\circ} \mathrm{E}-150^{\circ} \mathrm{E}, 2^{\circ} \mathrm{N}-50^{\circ} \mathrm{N}\right)$

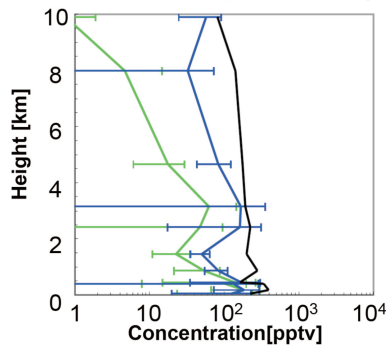

(f) INTEX-B

(Over Pacific)

(g) TRACE-P

(Pacific)
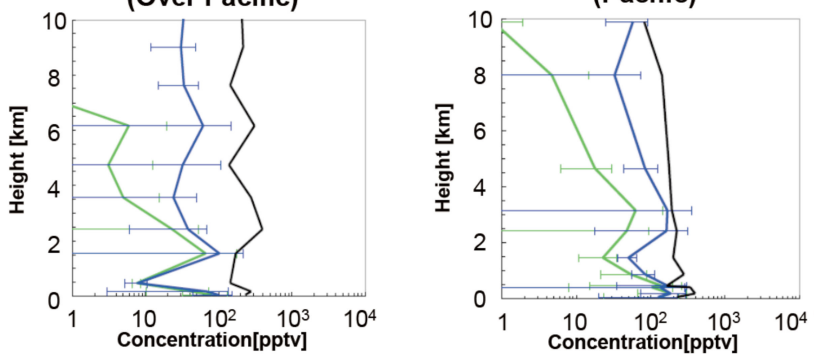

Fig. 6. Vertical profiles of the simulated and observed sulfate mixing ratios during the INTEX-A, the INTEX-B, and the TRACE-P. The black, blue, and green lines represent the observations, the simulations in NS and OS, respectively. The x-axis is mixing ratio in unit of pptv and the $y$-axis is height in meters. 
(a) ACE1



(c) INDOEX

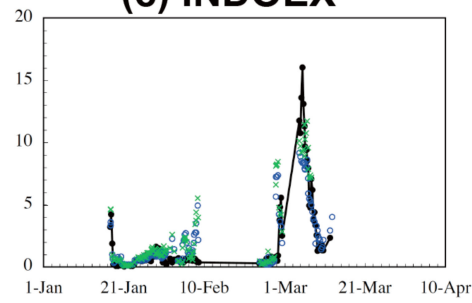

(e) NEAQS2002

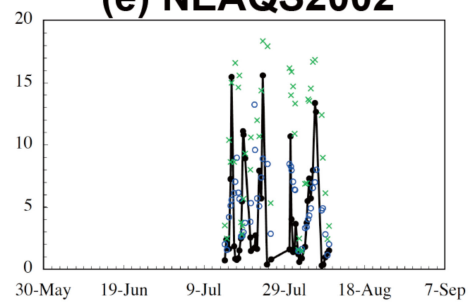

(g) TexAQS/GoMACCS

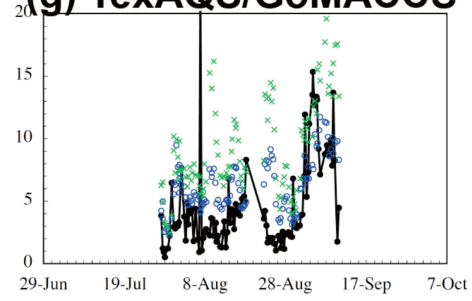

(b) ACE 2

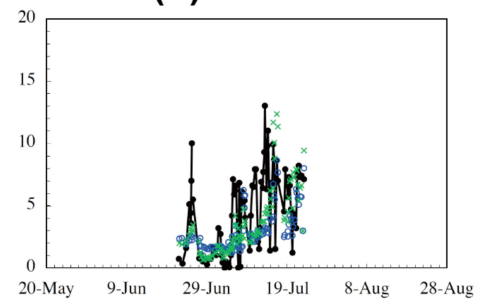

(d) ACE-Asia

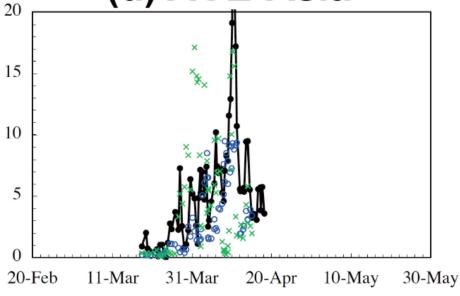

(f) NEAQS2004
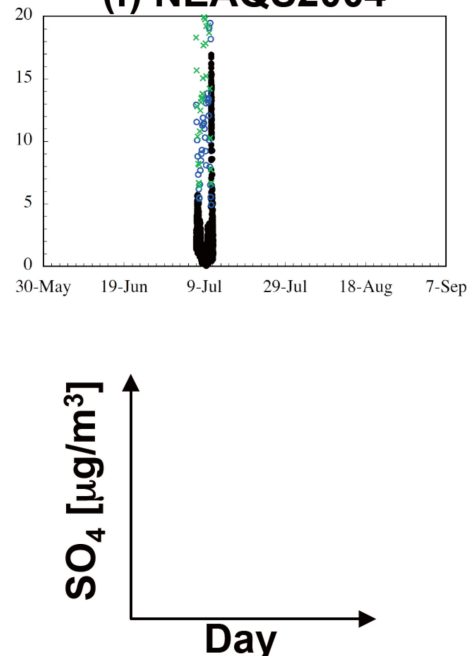

Fig. 7. Temporal sulfate mass concentrations by measurements in Quinn and Bates (2005) in black, simulations of NS in blue and simulations of OS in green, during different measurements periods (see text). The $\mathrm{x}$-axis values are date and the y-axis are sulfate concentrations in $\mu \mathrm{g} \mathrm{m}^{-3}$.

observations include the NASA Transport and Chemical Evolution over the Pacific aircraft mission (TRACE-P) conducted in February-April 2001 over the northwestern Pacific as summarized by Jacob et al. (2003), the Intercontinental Chemical Transport Experiment - North America aircraft mission (INTEX-NA) conducted in July-August 2004 over North America and the Atlantic summarized by Singh et al. (2006), and the Intercontinental Chemical Transport Experiment $-\mathrm{B}$ aircraft mission (INTEX-B) conducted in the spring of 2006 over Mexico City and the Pacific summarized by Singh et al. (2009). In OS, the simulated sulfate mixing ratios near the surface are overestimated, whereas those in the levels above $6 \mathrm{~km}$ are much underestimated as compared to observed values. Figure $6 b$, for example, shows the simulated sulfate mixing ratios in $\mathrm{OS}$ at altitude of $6 \mathrm{~km}$ are much less than 100 pptv, whereas those in NS are approximately 100 pptv. From these comparisons, we conclude that the vertical profiles of simulated sulfate mixing ratios in NS are much closer to the observations in comparison with the simulated results obtained from OS. The improvement of vertical profiles in NS probably stems from the increase in the sulfate production rate under lower $\mathrm{SO}_{2}$ concentrations as shown in Sect. 4.1.

\subsection{Oceans}

In this section, we compare the simulated sulfate field with observations over ocean areas. We use datasets including ship measurements conducted by a group of the Pacific Marine Environmental Laboratory, NOAA (e.g. Quinn and Bate, 
2005) shown in Fig. 7. As shown over lands in the previous subsection, the simulated sulfate concentrations near the surface in NS are lower than those in OS and are comparable to the observation values. Over oceans near lands, i.e. outflow regions, this tendency is shown in Fig. $7 \mathrm{~d}-\mathrm{g}$, which are several ship measurements conducted by the Asian Aerosol Characterization Experiment (ACE Asia) around the Japan Sea during March-April 2001 by Huebert et al. (2003), by the New England Air Quality Study (NEAQS) during July-August 2002 and 2004, and by the Texas Air Quality Study/Gulf of Mexico Atmospheric Composition and Climate Study (TexAQS/GoMACCS) in August 2006 (Quinn and Bates, 2003; Bates et al., 2006, 2008), respectively. Over remote oceans, on the other hand, the differences in the simulated sulfate concentration between NS and OS are very small as shown in Fig. 7a and c, whose observations are carried out under the first Aerosol Characterization Experiments (ACE-1) around the Central Pacific and south of Australia during October-December 1995 by Bates et al. (1998a, b) and the Indian Ocean Experiment (INDOEX) ship measurement in January-March 1999 by Ramanathan et al. (2001). In other remote sites such as Fanning Island located at the central Pacific ocean, the simulated sulfate concentrations in both NS and OS are significantly lower than observed values (not shown). This underestimation is also shown in the simulated vertical profiles of the sulfate mixing ratios compared to observed values on the flight during the TRACE-P and the INTEX-B (Fig. 6). A future study is needed to correct this underestimation especially for better estimation of the indirect radiative forcing of anthropogenic aerosols, because we usually assume that the background aerosols represent natural aerosols.

\section{Sulfur budget estimation}

In this section, global budgets of simulated sulfate and $\mathrm{SO}_{2}$ are compared with other modeling studies. Fig. 1 shows that the results of NS are more consistent with those of other AEROCOM models with its larger both sulfate column burden and fraction above $5 \mathrm{~km}$, whereas OS, i.e. the original SPRINTARS model, are the lowest among AEROCOM models, because NS generally suppresses the sulfate formation at the surface and increases the sulfate formation in the upper atmosphere above approximately $6 \mathrm{~km}$ as shown in Sect. 5. It should be noted that the fraction of the simulated sulfate column burden in the polar region above $80^{\circ}$ degree is estimated to be $1.6 \%$ in NS which is larger than $0.3 \%$ in OS, though the magnitude in NS is still smaller than those of other AEROCOM models by 2-6\% (Textor et al., 2007). In conclusion, these improvements of consistency of NS with other AEROCOM models in the vertical and horizontal distributions of sulfur compounds seem to be related with each other, even though the differences in the global sulfate distribution between NS and other AEROCOM models exist. For

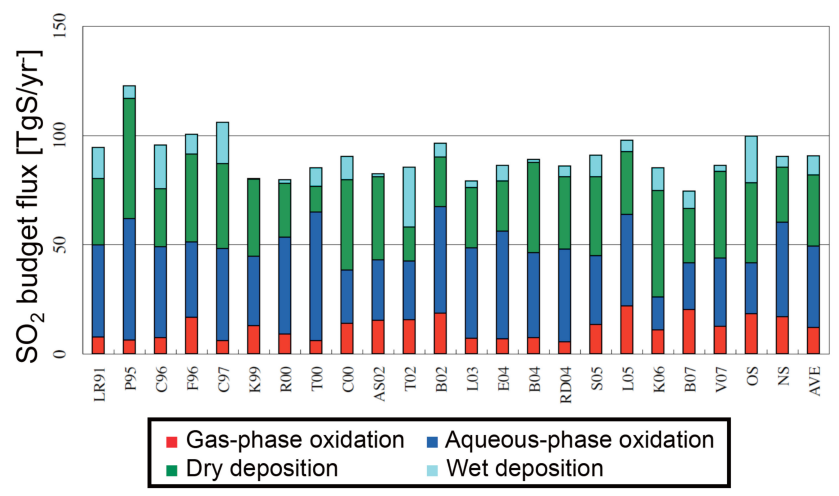

Fig. 8. Global annual mean $\mathrm{SO}_{2}$ budget in this simulations: LR91 (Langner and Rodhe, 1991), P95 (Pham et al., 1995), C96 (Chin et al., 1996), F96 (Feichter et al., 1997), C97 (Chuang et al., 1997), K99 (Koch et al., 1999), R00 (Rasch et al., 2000), T00 (Takemura et al., 2002), C00 (Chin et al., 2000), AS02 (Adams and Seinfeld, 2002), T02 (Takemura et al., 2002), B02 (Boucher et al., 2002), L03 (Liao et al., 2003), E04 (Easter et al., 2004), B04 (Berglen et al., 2004), RD04 (Rodriguez and Daddub, 2004), S05 (Spracken et al. 2005), L05 (Liu et al., 2005), K06 (Koch et al., 2006), B07 (Bauer et al., 2007), and V07 (Verma et al., 2007), respectively. The NS and OS represent simulations in this study and the original SPRINTARS. The AVE represents averaged values.

example, our simulation with MIROC-AGCM tends to have larger sulfate concentrations over low latitudes and smaller ones over high latitudes compared to other AGCM simulations presented by Liao et al. (2003). The sulfate distribution depends on sulfur chemistry, deposition (mainly wet deposition), and transport (e.g. Rasch et al., 2001). After the modification of the sulfur chemistry, differences in the sulfate distribution still remain, so that they are probably caused by differences in wet deposition and transport. The wet deposition depends not only on the radius and wet growth of the particles but also on precipitation flux, cloud fraction, and advection of aerosol. As we mentioned in Sect. 1, the difference in the radius and wet growth of sulfate aerosols among sulfur chemistry models is not so large. Therefore, the differences in the sulfate concentrations over low latitudes are caused by (1) cloud and precipitation, which are determined mainly by schemes of the boundary layer and/or the cloud and precipitation, and (2) transport pattern, which is determined by schemes of the boundary layer and advection; but a detailed study is our future work.

Table 5 shows global budgets of sulfur components (DMS, $\mathrm{SO}_{2}$, and sulfate) obtained in NS and OS. Even the differences in the processes of DMS oxidation and its dry deposition between NS and OS exist, the difference in the production amount of $\mathrm{SO}_{2}$ by DMS oxidation is within $10 \%$. Therefore, total $\mathrm{SO}_{2}$ emissions in NS are almost same as those in OS. The following four loss processes of $\mathrm{SO}_{2}$ are considered in NS and $\mathrm{OS}: \mathrm{SO}_{2}$ oxidation by $\mathrm{OH}$ in the gas phase, $\mathrm{SO}_{2}$ oxidation by $\mathrm{H}_{2} \mathrm{O}_{2}$ and $\mathrm{O}_{3}$ in the aqueous 
Table 5. Global budgets $\left(\mathrm{TgS} \mathrm{yr}^{-1}\right.$ ) of sulfur components (DMS, $\mathrm{SO}_{2}$ and sulfate) in the simulations using NS and OS. The figures in blankets represent contributions to the total budget.

\begin{tabular}{|c|c|c|}
\hline & OS & NS \\
\hline \multicolumn{3}{|l|}{ DMS } \\
\hline Emission & +17.0 & +16.9 \\
\hline Emission from ocean & $+17.0(100 \%)$ & $+16.9(100 \%)$ \\
\hline Loss process & -17.0 & -16.9 \\
\hline Oxidation by $\mathrm{OH}$ (to $\mathrm{SO}_{2}$ ) & $-15.5(91 \%)$ & $-16.9(89 \%)$ \\
\hline Oxidation by $\mathrm{OH}$ (to aerosol) & $-0.0\left(0 \%\right.$, as $\left.\mathrm{SO}_{4}^{2-}\right)$ & $-1.9(11 \%$, as MSA $)$ \\
\hline Dry deposition & $-1.5(9 \%)$ & $0(0 \%)$ \\
\hline \multicolumn{3}{|l|}{$\mathrm{SO}_{2}$} \\
\hline Emission & +92.5 & +92.0 \\
\hline Fossil fuel combustion & $+69.3(75 \%)$ & $+69.3(75 \%)$ \\
\hline Biomass burning & $+2.9(3 \%)$ & $+2.9(3 \%)$ \\
\hline Volcano & $+4.8(5 \%)$ & $+4.8(5 \%)$ \\
\hline DMS oxidation & $+15.5(17 \%)$ & $+15.0(17 \%)$ \\
\hline Loss process & -92.5 & -92.0 \\
\hline Gas-phase oxidation & $-16.5(18 \%)$ & $-17.4(19 \%)$ \\
\hline Aqueous-phase oxidation & $-21.1(23 \%)$ & $-43.7(48 \%)$ \\
\hline Wet deposition & $-19.9(22 \%)$ & $-5.0(5 \%)$ \\
\hline Dry deposition & $-35.0(38 \%)$ & $-25.9(28 \%)$ \\
\hline \multicolumn{3}{|l|}{ Sulfate } \\
\hline Production & +37.6 & +61.1 \\
\hline $\mathrm{SO}_{2}$ gas-phase oxidation & $+16.5(44 \%)$ & $+17.4(28 \%)$ \\
\hline $\mathrm{SO}_{2}$ aqueous-phase oxidation & $+21.1(56 \%)$ & $+43.7(72 \%)$ \\
\hline Loss process & -37.6 & -61.1 \\
\hline Wet deposition & $-31.8(85 \%)$ & $-53.5(88 \%)$ \\
\hline Dry deposition & $-5.8(15 \%)$ & $-7.6(12 \%)$ \\
\hline Gravitational settling & $0.0(0 \%)$ & $-0.0(0 \%)$ \\
\hline
\end{tabular}

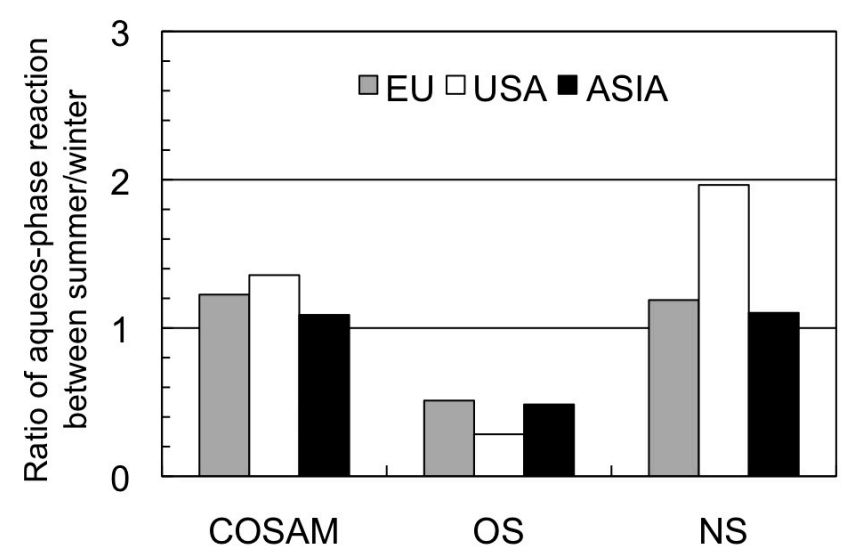

Fig. 9. Ratios of $\mathrm{SO}_{2}$ aqueous-phase oxidation flux in summer to that in winter over three industrial regions using the COSAM exercises, OS and NS, respectively.

phase, dry deposition, and wet deposition by precipitation. Among these processes, the gas-phase oxidation of $\mathrm{SO}_{2}$ in NS is almost same as that in OS as estimated to be 17.4
[TgS yr$\left.{ }^{-1}\right]$ (19\% for the total $\mathrm{SO}_{2}$ loss process) in NS and $16.5\left[\mathrm{TgS} \mathrm{yr}^{-1}\right]$ (18\% for the total $\mathrm{SO}_{2}$ loss process) in OS, which are within the uncertainty among other model estimates 5.7-22.0 [ $\left.\mathrm{TgS} \mathrm{yr}^{-1}\right]$ (references in Fig. 8). On the other hand, a large difference between NS and OS occurs in the $\mathrm{SO}_{2}$ aqueous-phase oxidation, and wet deposition and dry deposition. In $\mathrm{OS}, \mathrm{SO}_{2}$ budgets for aqueous-phase reaction and wet deposition are estimated to be $19.9\left[\mathrm{TgS} \mathrm{yr}^{-1}\right]$ (22\% for the total $\mathrm{SO}_{2}$ loss process) and $21.2\left[\mathrm{TgS} \mathrm{yr}^{-1}\right]$ ( $23 \%$ for the total $\mathrm{SO}_{2}$ loss process), respectively, whereas those are estimated in NS to be 43.7 [ $\mathrm{TgS} \mathrm{yr}^{-1}$ ] (48\% for the total $\mathrm{SO}_{2}$ loss process) and $5.0\left[\mathrm{TgS} \mathrm{yr}^{-1}\right]$ (5\% for the total $\mathrm{SO}_{2}$ loss process), respectively. The differences are mainly caused by a difference in the sulfate production efficiency. As a result, a correlation of the simulated $\mathrm{SO}_{2}$ budgets in NS between wet deposition and aqueous-phase reaction is much closer to that by other modeling studies (see Fig. 2). In the other modeling studies, the $\mathrm{SO}_{2}$ budget is estimated to be $15.2-55.5\left[\mathrm{TgS} \mathrm{yr}^{-1}\right]$ for the aqueous-phase reaction and $0.2-19.9\left[\mathrm{TgS} \mathrm{yr}^{-1}\right]$ for the wet deposition, respectively (references in Fig. 8). In the dry deposition, the $\mathrm{SO}_{2}$ flux 
(a) Retrieved AOT by Terra/MODIS

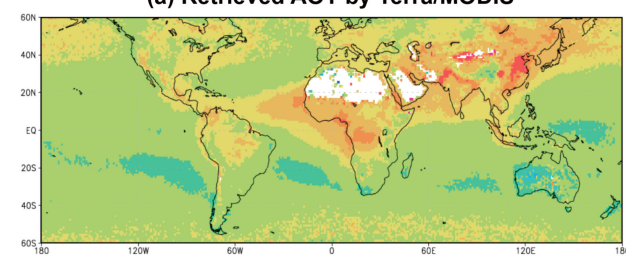

(c) Simulated AOT in this study



(b) Retrieved AOT by Terra/MISR

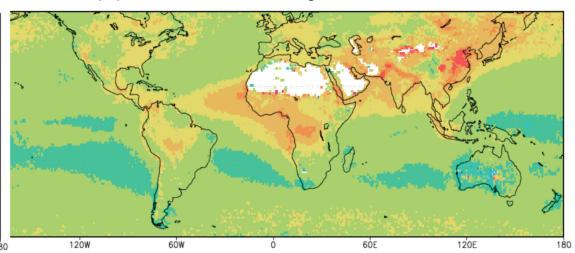

(d) Simulated AOT in the original SPRINTARS

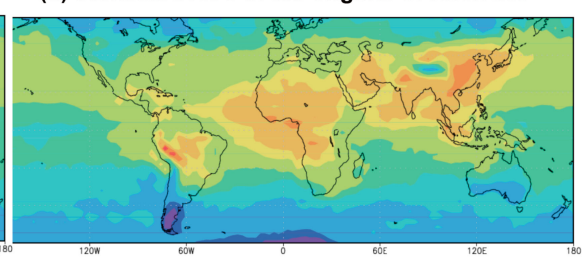

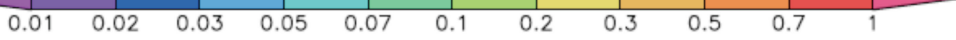

Fig. 10. Annual mean AOT distributions observed by (a) Terra/MODIS, (b) Terra/MISR, (c) NS and (d) OS, respectively, for the year 2003.

in OS is the largest amount $\left(35.0\left[\mathrm{TgS} \mathrm{yr}^{-1}\right]\right.$ or $38 \%$ for the total $\mathrm{SO}_{2}$ loss process) in the $\mathrm{SO}_{2}$ loss processes mainly because the dry deposition rate in OS is overestimated due to lack of the term $R_{\mathrm{c}}$. After inclusion of the term $R_{\mathrm{c}}$ to the dry deposition process in NS, the $\mathrm{SO}_{2}$ budget for dry deposition becomes to be 25.9 [ $\mathrm{TgS} \mathrm{yr}^{-1}$ ] (28\% for the total $\mathrm{SO}_{2}$ loss process), which is consistent with other model estimates 22.7-55.0 [ $\mathrm{TgS} \mathrm{yr}^{-1}$ ] (references in Fig. 8). Model estimates of the global annual $\mathrm{SO}_{2}$ budget are illustrated in Fig. 8 in terms of the four main processes. Finally the sulfate production rates from $\mathrm{SO}_{2}$ oxidation are estimated to be 37.6 [ $\left.\mathrm{TgS} \mathrm{yr}^{-1}\right]$ in OS and $61.1\left[\mathrm{TgS} \mathrm{yr}^{-1}\right]$ in NS, respectively, whereas other model estimates are in the range of 26.2-67.6 [TgS yr$\left.{ }^{-1}\right]$ (references in Fig. 8). The ratio of the sulfate wet deposition to the sulfate total loss processes is estimated to be $85 \%$ in OS and $88 \%$ in NS, so that the contribution is almost equal to each other even though more physical-based dry deposition model for the sulfate is used in NS.

Figure 9 shows ratios of simulated $\mathrm{SO}_{2}$ flux in the aqueous-phase reaction in summer to that in winter in three industrial areas using NS, OS and models used in the COSAM comparison, which estimates averaged budget of simulated $\mathrm{SO}_{2}$ using different ten model results (Roelofs et al., 2001). In OS, winter-time aqueous-phase reaction fluxes are generally so large that the ratio becomes smaller than those of NS and the COSAM comparison. This low value in OS is caused by the treatment of use for offline $\mathrm{H}_{2} \mathrm{O}_{2}$ distribution as mentioned in Sect. 4.4. The ratio reflects a seasonal variation of $\mathrm{SO}_{2}$ aqueous-phase oxidation, so that we also find a big difference in the seasonality between the simplified and improved sulfur schemes.

\section{Aerosol direct radiative forcing}

In this Sect. we discuss an evaluation of the aerosol optical and radiative fields, i.e. aerosol optical thickness (AOT) and aerosol direct radiative forcing (ADRF). Figure 10 shows annually averaged global AOT distributions simulated by both NS and OS and observed by both Terra/MODIS and Terra/MISR. Large differences are found over oceans, where the satellite-observed AOT is more than at least 0.1 , whereas the simulated AOT is generally less than 0.1. There are several problems for accurate evaluation of AOT over ocean with both simulation and satellite observation. With regard to satellite observation, the retrieval of the AOT over oceans often suffers from cloud and whitecap contaminations and an ill assumption of the aerosol optical properties and sphericity of the particle shape (e.g. Chin et al., 2002; Chu et al., 2005). Especially the former two reasons lead to an overestimation of the retrieved AOT over oceans, especially the North Pacific and South Pacific. Chu et al. (2005) suggests that the retrieved AOT from MODIS tends to be positively biased in the dusty conditions. Additionally Winker (2008) showed differences in the retrieved AOT from MODIS and CALIPSO (Cloud-Aerosol Lidar and Infrared Pathfinder Satellites Observations) and pointed out remarkable overestimations of the AOT from MODIS in the AOT ranging from 0 to 0.1 . On the other hand, SPRINTARS and most GCMs also have problems to simulate AOT especially over oceans (e.g. Takemura et al., 2002; Kinne et al., 2006; Yu et al., 2006). It seems that most GCMs underestimate background aerosols or transported aerosols from continents.

Figure 11 shows a histogram of the simulated and observed annual mean AOT for each area. In both Figs. 10 and 11, we find improvements of the simulated AOT in NS around areas such as Northeastern America, the North Atlantic, Europe, Eurasia continent, the North Pacific, the 


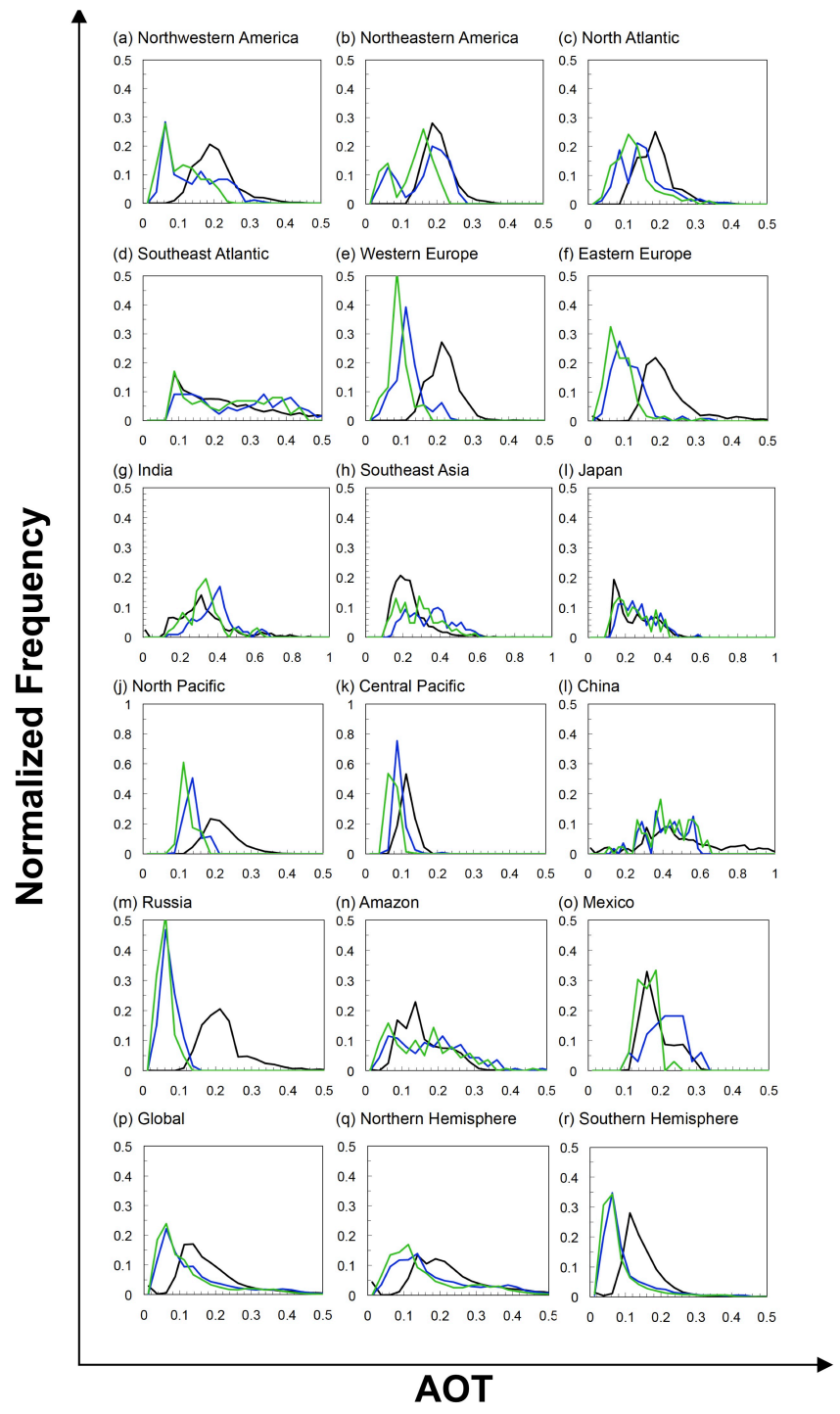

Fig. 11. Histograms of annual mean AOT calculated by two simulations (NS in blue and OS in green) and in the satellite observations (Terra/MODIS in black, Aqua/MODIS in light grey, and Terra/MISR in grey). The regions are West America $\left(120^{\circ} \mathrm{W}-\right.$ $\left.85^{\circ} \mathrm{W}, 15^{\circ} \mathrm{N}-55^{\circ} \mathrm{N}\right)$, East America $\left(85^{\circ} \mathrm{W}-60^{\circ} \mathrm{W}, 15^{\circ} \mathrm{N}-55^{\circ} \mathrm{N}\right)$, North Atlantic $\left(60^{\circ} \mathrm{W}-30^{\circ} \mathrm{W}, 15^{\circ} \mathrm{N}-55^{\circ} \mathrm{N}\right)$, Southeast Atlantic $\left(25^{\circ} \mathrm{W}-5^{\circ} \mathrm{E}, 25^{\circ} \mathrm{S}-5^{\circ} \mathrm{E}\right)$, West Europe $\left(15^{\circ} \mathrm{W}-20^{\circ} \mathrm{E}, 35^{\circ} \mathrm{N}-\right.$ $\left.65^{\circ} \mathrm{N}\right)$, East Europe $\left(20^{\circ} \mathrm{E}-55^{\circ} \mathrm{E}, 35^{\circ} \mathrm{N}-65^{\circ} \mathrm{N}\right)$, India $\left(60^{\circ} \mathrm{E}-\right.$ $\left.90^{\circ} \mathrm{E}, 0-30^{\circ} \mathrm{N}\right)$, Southeast Asia $\left(90^{\circ} \mathrm{E}-125^{\circ} \mathrm{E}, 10^{\circ} \mathrm{S}-25^{\circ} \mathrm{N}\right)$, Japan $\left(125^{\circ} \mathrm{E}-150^{\circ} \mathrm{E}, 15^{\circ} \mathrm{N}-45^{\circ} \mathrm{N}\right)$, North Pacific $\left(160^{\circ} \mathrm{E}-\right.$ $\left.140^{\circ} \mathrm{W}, 30^{\circ} \mathrm{N}-50^{\circ} \mathrm{N}\right)$, Central Pacific $\left(150^{\circ} \mathrm{E}-130^{\circ} \mathrm{W}, 10^{\circ} \mathrm{S}-\right.$ $\left.10^{\circ} \mathrm{N}\right)$, China $\left(100^{\circ} \mathrm{E}-125^{\circ} \mathrm{E}, 25^{\circ} \mathrm{N}-45^{\circ} \mathrm{N}\right)$, Russia $\left(50^{\circ} \mathrm{E}-\right.$ $\left.100^{\circ} \mathrm{E}, 45^{\circ} \mathrm{N}-65^{\circ} \mathrm{N}\right)$, Amazon $\left(70^{\circ} \mathrm{W}-40^{\circ} \mathrm{W}, 40^{\circ} \mathrm{S}-0\right)$, Mexico $\left(110^{\circ} \mathrm{W}-80^{\circ} \mathrm{W}, 5^{\circ} \mathrm{N}-15^{\circ} \mathrm{N}\right)$, the globe $\left(60^{\circ} \mathrm{S}-60^{\circ} \mathrm{N}\right)$, the $\mathrm{NH}(0-$ $\left.60^{\circ} \mathrm{N}\right)$ and the $\mathrm{SH}\left(0-60^{\circ} \mathrm{S}\right)$. The $\mathrm{x}$-axis values are AOT values and the $y$-axis values are values of normalized frequency.
Central Pacific, the coast of Africa to the Atlantic, and the Arctic. The AOT in NS is higher than the AOT in OS by $0.01-0.05$, because of the increase in the sulfate column burden. These differences are also discussed in terms of the column burden in Sect. 5. The magnitudes of this difference between NS and OS are smaller than those among different satellites. In other areas especially tropical and subtropical areas, i.e. India, Southeast Asia, South Asia, and Mexico, the AOT in NS rather than in OS tends to be larger than the satellite-observed AOT by at most 0.1 . As discussed in Sect. 6, comparisons with other model results also suggest that this overestimation of AOT in NS is caused both by the overestimation of the sulfate concentrations and by the tendency in our GCM of high gradients of the aerosol distribution from the equator to the Poles at high altitudes. The latter means that simulated aerosols in the MIROC AGCM tend to concentrate around the low latitudes. Over these areas, it is difficult for AGCM to accurately simulate fields of clouds and precipitation and then to accurately simulate sulfate formation in the aqueous-phase and relative humidity (RH), which can also determine AOT. At the same time, the observed AOT over such areas can relatively be uncertain due to the presence of large clouds. Around the clouds, satellite-observed AOT tends to be larger with suffering from difficulty of retrieval mainly due to 3-D radiation bias (Wen et al., 2007). That means that the satellite-observed AOT near the cloudy areas is still highly uncertain, and therefore it is concluded that the validation of the simulated AOT using satellite-observed AOT over the tropics and the subtropics is relatively difficult.

Global annual mean ADRFs due to anthropogenic sulfate in NS and OS are compared with other studies. The ADRFs due to anthropogenic sulfate are estimated to be $-0.35 \mathrm{~W} \mathrm{~m}^{-2}$ by the AEROCOM exercises (Schulz et al., 2006) and $-0.4 \pm 0.2 \mathrm{~W} \mathrm{~m}^{-2}$ by the IPCC-AR 4 assessment (Forster et al., 2007), respectively. The ADRF for NS is estimated to be $-0.26 \mathrm{~W} \mathrm{~m}^{-2}$, whereas that for OS is estimated to be $-0.18 \mathrm{~W} \mathrm{~m}^{-2}$. Using the AEROCOM emission inventory provided by Dentener et al. (2006), the ADRFs for NS and $\mathrm{OS}$ are estimated to be $-0.30 \mathrm{~W} \mathrm{~m}^{-2}$ and $-0.21 \mathrm{~W} \mathrm{~m}^{-2}$, respectively. The difference in the ADRF for NS and OS is large enough for us to conclude that the improvement of the sulfur scheme is important for the estimation of the ADRF due to sulfate. The improvement brings increases in the simulated sulfate column burden and then causes increases in the ADRF due to sulfate. This is why the differences in the simulated ADRF for NS and the other models are reduced with respect to those between OS and the other models (see Fig. 1). Judging from the validation of the simulated sulfate in NS and OS in Sect. 5, we can conclude that the sulfate simulations in NS are much better than those in OS; therefore the simulated ADRF for NS is more reliable than that for OS. In addition, we can also conclude that the nature of the sulfur scheme has a large contribution to the uncertainty for the ADRF estimation. 
(a) The original SPRINTARS

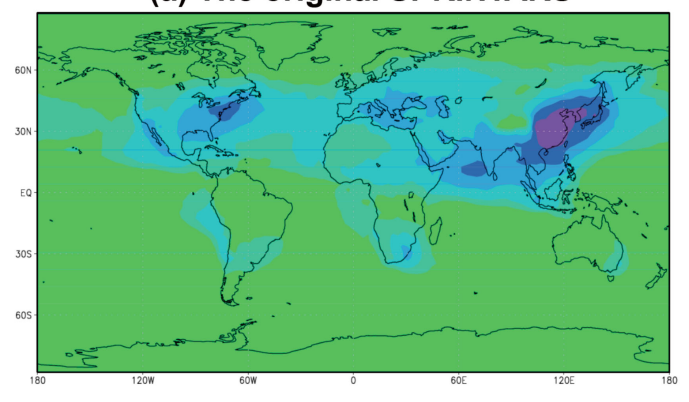

(b) This study

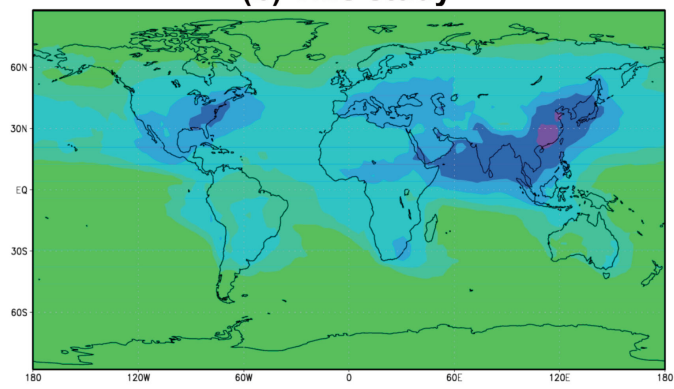

(c) Difference (This study-original SPRINTARS)

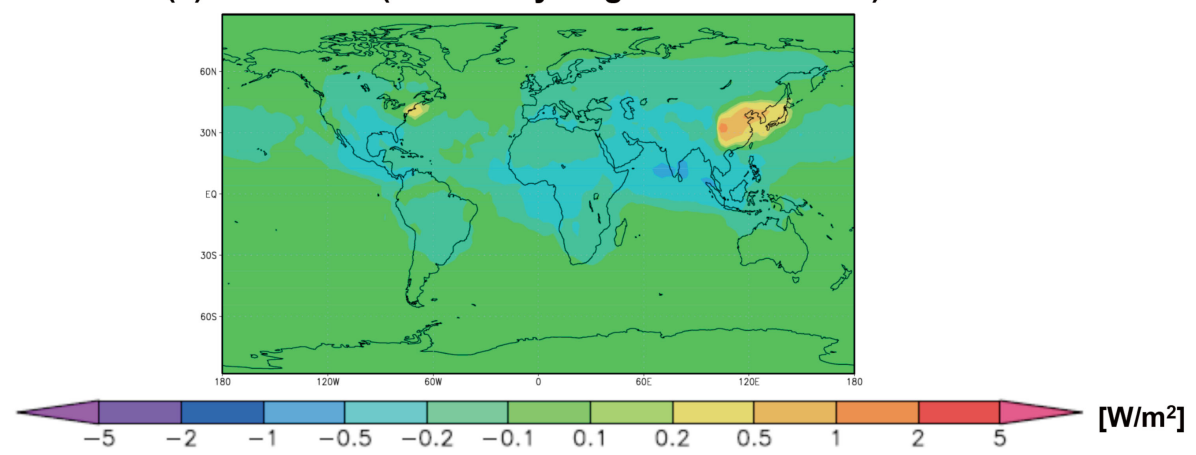

Fig. 12. Annual mean aerosol radiative forcings due to anthropogenic sulfate components in (a) OS, (b) NS, and (c) the difference between NS and OS.

The annual averaged ADRF due to anthropogenic sulfate for NS and the difference in the ADRFs between NS and OS are shown in Fig. 12. The improvement of the sulfur scheme causes decreases in the ADRF over China with a range of $0.2-1 \mathrm{~W} \mathrm{~m}^{-2}$, whereas it causes increases in the ADRF near aerosol source areas such as North America and Southeast Asia with ranges of $0.5-1 \mathrm{~W} \mathrm{~m}^{-2}$ and usually over land with ranges of $0.2-0.5 \mathrm{~W} \mathrm{~m}^{-2}$, respectively. The big change in the radiative forcing over East Asia is mainly caused by the difference in the solution in the sulfur aqueous-phase reaction as shown in Table 4. Over oceans, the ratios of the differences between NS and OS exceed 2, so that the impacts of the new module are large.

In summary, the improvement of the sulfur scheme has a large impact on the radiative forcings. This study suggests that these improvements of the basic components in sulfur simulations are important not only for their proper simulations but also for their radiative impacts through the aerosol direct effect.

\section{Conclusions}

One of the most important contributors of the anthropogenic aerosol radiative forcing is the sulfate aerosol, because both the results given by Schulz et al. (2006) and Fig. 1 suggest that the uncertainty of radiative forcings due to anthropogenic aerosols are largely derived from the differences in the sulfate column burden and its vertical distributions. One of the possible reasons of the differences among models is that models adopt different simplified methods or different approximations of the sulfur processes. In this study, therefore, we investigated impacts of different parts in the sulfur chemistry module of a global aerosol model, SPRINTARS, on the sulfate distribution and its radiative forcing. We used simplified and more physically based methods of representing sulfur chemistry processes especially $\mathrm{SO}_{2}$ reactions in the aqueous-phase, $\mathrm{H}_{2} \mathrm{O}_{2}$ chemistry, and dry deposition process of sulfur components. The results showed that the difference in the aqueous-phase sulfur chemistry calculation among these treatments had the largest impact on the sulfate distribution with a relative bias of $70-160 \%$. The impact of the difference in the $\mathrm{pH}$ calculation in the aqueous phase among this study was the smallest with a relative bias of less than $5 \%$. The other treatments had relative biases of at most $20 \%$. Introduction of all the improvements mentioned above gave lower sulfate concentrations near the surface and higher sulfate column burdens compared to the original method used in the SPRINTARS model. That means that the model results become more comparable to in-situ measurements than those in the original method. At the same time, these improvements also led the computed sulfate column burdens and its vertical distributions in good agreement with other AEROCOM model values. As a result, the global annual mean aerosol direct radiative forcings (ADRFs) due 
to anthropogenic sulfate was estimated to be $-0.3 \mathrm{~W} \mathrm{~m}^{-2}$, whereas that in the original SPRINTARS was $-0.2 \mathrm{~W} \mathrm{~m}^{-2}$. The magnitude of the difference in the ADRF between original and improved methods was approximately $50 \%$ of the uncertainty among estimates by the world's global aerosol models reported by the IPCC-AR4 assessment report. Findings in the present study, therefore, may suggest that the model differences in the simplifications of the sulfur processes are still a part of the large uncertainty in their simulated radiative forcings.

\section{Supplementary material related to this article is available online at: http://www.atmos-chem-phys.net/11/10889/2011/ acp-11-10889-2011-supplement.pdf.}

Acknowledgements. Some of the authors were supported by projects of JAXA/EarthCARE, MEXT/VL for Climate System Diagnostics, MOE/Global Environment Research Fund B-0083 and A-1101, NIES/GOSAT, NIES/CGER, and MEXT/RECCA/SALSA. We acknowledge the NOAA/OAR/ESRL PSD, Boulder, Colorado, USA, for providing the NCEP Reanalysis Derived data; the HadISST data from Hadley Centre, UK Met Office, for providing SST and Sea ice data and the NASA science team for providing the level 3 product of aerosol optical thickness from MODIS and MISR. We also acknowledge many observers and researchers at IMPROVE, EMEP, EANET, AERONET, the University of Miami (J. M. Prospero and D. L. Savoie), NOAA/PMEL, and NASA for INTEX A and B projects.

Edited by: E. Highwood

\section{References}

Adams P. J. and Seinfeld, J. H.: Predicting global aerosol size distributions in general circulation models, J. Geophys. Res., 107, 4370, doi:10.1029/2001JD001010, 2002.

Adams, P. J., Seinfeld, J. H., and Koch, D. M.: Global concentrations of tropospheric sulfate, nitrate, and ammonium aerosol simulated in a general circulation model, J. Geophys. Res., 104, 13791-13823, 1999.

Barrie, L. A., Yi, Y., Leaitch, W. R., Lohmann, U., Kasibhatla, P., Roelofs, G.-J., Wilson, J., McGovern, F., Benkovitz, C., Méliéres, M. A., Law, K., Prospero, J., Kritz, M., Bergmann, D., Bridgeman, C., Chin, M., Christensen, J., Easter, R., Feichter, J., Land, C., Jeuken, A., Kjellström, E., Koch, D., and Rasch, P.: A comparison of large-scale atmospheric sulphate aerosol models (COSAM): overview and highlights, Tellus, 53B, 615-645, 2001.

Barth, M. C., Rasch, P. J., and Kiehl, J. T.: Sulfur chemistry in the National Center for Atmospheric Research Community Climate Model: Description, evaluation, features, and sensitivity to aqueous chemistry, J. Geophys. Res., 105, 1387-1415, 2000.

Bates, T. S., Charlson, R. J., and Gammon, R. H.: Evidence for the climate role of marine biogenic sulphur, Nature, 329, 319-321, 1987.
Bates, T. S., Huebert, B. J., Gras, J. L., Griffiths, F. B., and Durkee, P. A.: International Global Atmospheric Chemistry (IGAC) Project's First Aerosol Characterization Experiment (ACE 1): Overview, J. Geophys. Res., 103, 16297-16318, 1998a.

Bates, T. S., Kapustin, V. N., Quinn, P. K., Covert, D. S., Coffman, D. J., Mari, C., Durkee, P. A., De Bruyn, W. J., and Saltzman, E. S.: Process controlling the distribution of aerosol particles in the lower marine boundary layer during the First Aerosol Characterization Experiment (ACE 1), J. Geophys. Res., 103, 1636916383, 1998b.

Bates, T. S., Anderson, T. L., Baynard, T., Bond, T., Boucher, O., Carmichael, G., Clarke, A., Erlick, C., Guo, H., Horowitz, L., Howell, S., Kulkarni, S., Maring, H., McComiskey, A., Middlebrook, A., Noone, K., O’Dowd, C. D., Ogren, J., Penner, J., Quinn, P. K., Ravishankara, A. R., Savoie, D. L., Schwartz, S. E., Shinozuka, Y., Tang, Y., Weber, R. J., and Wu, Y.: Aerosol direct radiative effects over the northwest Atlantic, northwest Pacific, and North Indian Oceans: estimates based on in-situ chemical and optical measurements and chemical transport modeling, Atmos. Chem. Phys., 6, 1657-1732, doi:10.5194/acp-6-1657-2006, 2006.

Bates, T. S., Quinn, P. K., Coffman, D., Schulz, K., Covert, D. S. Johnson, J. E., Williams, E. J., Lerner, B. M., Angevine, W. M., Tucker, S. C., Brewer, W. A., and Stohl, A.: Boundary layer aerosol chemistry during TexAQS/GoMACCS 2006: Insights into aerosol sources and transformation processes, J. Geophys. Res., 113, D00F01, doi:10.1029/2008JD010023, 2008.

Bauer, S. E., Koch, D., Unger, N., Metzger, S. M., Shindell, D. T., and Streets, D. G.: Nitrate aerosols today and in 2030: a global simulation including aerosols and tropospheric ozone, Atmos. Chem. Phys., 7, 5043-5059, doi:10.5194/acp-7-5043-2007, 2007.

Berglen, T. F., Berntsen, T. K., Isaksen, I. S. A., and Sundet, J. K. A global model of the coupled sulfur/oxidant chemistry in the troposphere: The sulfur cycle, J. Geophys. Res., 109, D19310, doi.10.1029/2003JD003948, 2004.

Boucher, O., Pham, M., and Venkataraman, C.: Simulation of the atmospheric sulfur cycle in the Laboratoire de Meteorologie Dynamique General Circulation Model, Model description, mode evaluation and global European budgets, Note scientifuque de l'IPSL, n. 23, 2002.

Chin, M. A., Jacob, D. J., Gaedner, G. M., Foremanfowler, M. S., Spiro, P. A., and Savoie, D. L.: A global three-dimensional model of tropospheric sulfate, J. Geophys. Res., 101, 1866718690,1996

Chin, M., Rood, R. B., Lin, S.-J., Muller, J. F., and Thompson, A. M.: Atmospheric sulfur cycle in the global model GOCART: Model description and global properties, J. Geophys. Res., 105, 24671-24687, 2000.

Chin, M., Ginoux, P., Kinne, S., Torres, O., Holben, B. N., Duncan, B. N., Martin, R. V., Logan, J. A., Higurashi, A., and Nakajima, T.: Tropospheric aerosol optical thickness from the GOCART model and comparisons with satellite and sun photometer measurements, J. Atmos. Sci., 59, 461-483, 2002.

Chin, Mian, Diehl, T., Ginoux, P., and Malm, W.: Intercontinental transport of pollution and dust aerosols: implications for regional air quality, Atmos. Chem. Phys., 7, 5501-5517, doi:10.5194/acp7-5501-2007, 2007.

Chu, D. A., Remer L. A., Kaufman, Y. J., Schmid, B., Redemann, 
J., Knobelspiesse, K., Chem, J.-D., Livingston, J., Russell, P. B., Xiong, X., and Ridgway, W.: Evaluation of aerosol properties over ocean from Moderate Resolution Imaging Spectroradiometer (MODIS) during ACE-Asia, J. Geophys. Res., 110, D07308, doi:10.1029/2004JD005208, 2005.

Chuang, P. Y., Charlson, R. J., and Seinfeld, J. H.: Kinetic limitations on droplet formation in clouds, Nature, 390, 594-596, 1997.

Dentener, F., Kinne, S., Bond, T., Boucher, O., Cofala, J., Generoso, S., Ginoux, P., Gong, S., Hoelzemann, J. J., Ito, A., Marelli, L., Penner, J. E., Putaud, J.-P., Textor, C., Schulz, M., van der Werf, G. R., and Wilson, J.: Emissions of primary aerosol and precursor gases in the years 2000 and 1750 prescribed data-sets for AeroCom, Atmos. Chem. Phys., 6, 4321-4344, doi:10.5194/acp6-4321-2006, 2006.

Easter R. C., Ghan, S. J., Zhang, Y., Saylor, R. D., Chapman, E. G., Laulainen, N. S., Abdul-Razzak, H., Lenug, L. R., Bian, X., and Zaveri, R. A.: MIRAGE: Model description and evaluation of aerosols and trace gases, J. Geophys. Res., 109, D20210, doi:10.1029/2004JD004571, 2004.

Feichter, J., Kjellstrom, E., Rodhem, H., Dentener, F., Lelieveld, J., and Roelofs, G. J.: Simulation of the troposphere sulfur cycle in a global climate model, Atmos. Environ., 30, 1693-1707, 1996.

Forster, P., Ramaswamy, V., Artaxo, P., Berntsen, T., Betts, R., Fahey, D. W., Haywood, J., Lean, J., Lowe, D. C., Myhre, G., Nganga, J., Prinn, R., Raga, G., Schulz, M., Van Dorland, R.: Changes in Atmospheric Constituents and in Radiative Forcing, in: Climate Change 2007: The Physical Science Basis. Contribution of Working Group I to the Fourth Assessment Report of the Intergovernmental Panel on Climate Change, edited by: Solomon, S., Qin, D., Manning, M., Chen, Z., Marquis, M., Averyt, K. B., Tignor, M., and Miller, H. L., Cambridge University Press, Cambridge, United Kingdom and New York, NY, USA, 2007.

Gong, S. L., Barrie, L. A., Blanchet, J.-P., Salzen, K. V., Lohmann, U., Lesins, G., Spacek, L., Zhang, L. M., Girard, E., Lin, H., Leaitch, R., Leighton, H., Chylek, P., and Huang, P.: Canadian Aerosol Module: A size-segregated simulation of atmospheric aerosol processes for climate and air quality models 1. Module development, J. Geophy. Res., 108, 4007, doi:10.1029/2001JD002002, 2003.

Goto, D., Takemura, T., and Nakajima, T: Importance of global aerosol modeling including secondary organic aerosol formed from monoterpene, J. Geophys. Res., 113, D07205, doi:10.1029/2007JD009019, 2008.

Guenther, A., Hewitt, C. N., Erickson, D., Fall, R., Geron, C., Graedel, T., Harley, P., Klinger, L., Lerdau, M., McKay, W. A., Pierce, T., Scholes, B., Steincrecher, R., Tallamraju, R., Taylor, J., and Zimmerman, P. A.: Global-Model of Natural Volatile Organic-Compound Emissions, J. Geophys. Res., 100, 88738892, 1995.

Haywood, J. M. and Ramaswamy, V.: Global sensitivity studies of the direct radiative forcing due to anthropogenic sulfate and black carbon aerosols, J. Geophys. Res., 103, 6043-6058, 1998.

Heintzenberg, J., Covert, D. C., Van Dingenen, R.: Size distribution and chemical composition of marine aerosols: a compilation and review, Tellus, 52B, 1004-1122, 2000.

Hess M., Koepke, P. and Schult, I.: Optical Properties of Aerosols and Clouds: The Software Package OPAC, B. Am. Meteorol.
Soc., 79, 831-844, 1998.

Hobbs, P. V.: Introduction to atmospheric chemistry, Cambridge University Press, Cambridge, United Kingdom, 2000.

Hollway, T., Sakurai, T., Han, Z., Ehlers, S., Spak, S. N., Horowitz, L. W., Carmichael, G. R., Streets, D. G., Hozumi, Y., Ueda, H., Park, S. U., Fung, C., Kajino, M., Thongboonchoo, N., Engardt, M., Bennet, C., Hayami, H., Sartelet, K., Wang, Z., Matsuda, K., and Aman, M.: MICS-Asia II: Impact of global emissions on regional air quality in Asia, Atmos. Environ., 42, 3543-3561, 2008.

Huebert, B. J., Bates, T., Russell, P. B., Shi, G., Kim, Y. J., Kawamura, K., Carmichael, G., and Nakajima, T.: An overview of ACE-Asia: Strategies for quantifying the relationships between Asian aerosols and their climatic impacts, J. Geophys. Res., 108, 8633, doi:10.1029/2003JD003550, 2003.

Jacob, D. J., Crawford, J. H., Kleb, M. M., Connors, V. S., Bendura, R. J., Raper, J. L., Sachse, G. W., Gille, J. C., Emmons, L., and Heald, C. L.: Transport and Chemical Evolution over the Pacific (TRACE-P) aircraft mission: Design, execution, and first results, J. Geophys. Res., 108, 9000, doi:10.1029/2002JD003276, 2003.

K-1 Model Developers: K-1 coupled GCM (MIROC) description, K-1 Tech. Rep. 1, edited by: Hasumi, H. and Emori, S., Univ. of Tokyo, Tokyo, 2004.

Kinne, S., Schulz, M., Textor, C., Guibert, S., Balkanski, Y., Bauer, S. E., Berntsen, T., Berglen, T. F., Boucher, O., Chin, M., Collins, W., Dentener, F., Diehl, T., Easter, R., Feichter, J., Fillmore, D., Ghan, S., Ginoux, P., Gong, S., Grini, A., Hendricks, J., Herzog, M., Horowitz, L., Isaksen, I., Iversen, T., Kirkevåg, A., Kloster, S., Koch, D., Kristjansson, J. E., Krol, M., Lauer, A., Lamarque, J. F., Lesins, G., Liu, X., Lohmann, U., Montanaro, V., Myhre, G., Penner, J., Pitari, G., Reddy, S., Seland, O., Stier, P., Takemura, T., and Tie, X.: An AeroCom initial assessment - optical properties in aerosol component modules of global models, Atmos. Chem. Phys., 6, 1815-1834, doi:10.5194/acp-6-1815-2006, 2006.

Koch, D., Jacob, D., Tegen, I., Rind, D., and Chin, M: Tropospheric sulfur simulation and sulfate direct radiative forcing in the Goddard Institute for Space Studies general circulation model, J. Geophys. Res., 104, 23799-23822, 1999.

Koch, D., Schmidt, G. A., and Field, C. V.: Sulfur, sea salt, and radionuclide aerosols in GISS ModelE, J. Geophys. Res., 111, D6206, doi:10.1029/2004JD005550, 2006.

Langner, J. and Rodhe, H.: A Global Three-Dimensional Model of the Troposheric Sulfur Cycle, J. Atmos. Chem., 13, 225-263, 1991.

Liao, H., Adams, P. J., Chung, S. H., Seinfeld, J. H., Michley, L. J. and Jacob, D. J.: Interactions between tropospheric chemistry and aerosols in a unified general circulation model, J. Geophys. Res., 108, 4001, doi:10.1029/2001JD001260, 2003.

Liu, X. H. and Penner, J. E.: Effect of Mt. Pinatubo H2SO4/H2O aerosol on ice nucleation in the upper troposphere using a global chemistry and transport model (IMPACT), J. Geophys. Res., 107, 4141, doi:10.1029/2001JD000455, 2002.

Liu, X. H., Penner, J. E., and Herzog, M.: Global modeling of aerosol dynamics: Model description, evaluation, and interactions between sulfate and nonsulfate aerosols, J. Geophys. Res., 110, D18026, doi:10.1029/2004JD005674, 2005.

McFiggans, G., Artaxo, P., Baltensperger, U., Coe, H., Facchini, M. C., Feingold, G., Fuzzi, S., Gysel, M., Laaksonen, A., Lohmann, 
U., Mentel, T. F., Murphy, D. M., O'Dowd, C. D., Snider, J. R., and Weingartner, E.: The effect of physical and chemical aerosol properties on warm cloud droplet activation, Atmos. Chem. Phys., 6, 2593-2649, doi:10.5194/acp-6-2593-2006, 2006.

Nakajima, T., Tsukamoto, M., Tsushima, Y., Numaguti, A., and Kimura, T.: Modeling of the radiative process in an atmospheric general circulation model, Appl. Opt., 39, 4869-4878, 2000.

Park, R., Jacob, D. J., Field, B. D., Yantosca, R. M., and Chin, M.: Natural and transboundary pollution influences on sulfate-nitrate-ammonium aerosols in the United States: Implications for policy, J. Geophys. Res., 109, D15204, doi:10.1029/2003JD004473, 2004.

Pham, M., Müller, J.-F., Brasseur, G. P., Granier, C., and Megie, G. M.: A three-dimensional study of the tropospheric sulfur cycle, J. Geophys. Res., 100, 26061-26092, 1995.

Pitari, G., Rizi, V., Ricciardulli, L., and Visconti, G.: High-speed civil transport impact: Role of sulfate, nitric acid trihydrate, and ice aerosol studies with a two-dimensional model including aerosol physics, J. Geophys. Res., 98, 23141-23164, 1993.

Pitari, G., Mancini, E., Rizi, V., and Shindell, D. T.: Impact of future climate and emissions changes on stratosphere aerosols and ozone, J. Atmos. Sci., 59, 414-440, 2002.

Pitts, B. J. F., and Pitts Jr., J. N.: Chemistry of the Upper and Lower Atmosphere, Theory, Experiments, and Applications, Academic Press., 970 pp., 1999.

Prospero, J. M., Savoie, D. L., and Arimoto, R.: Long-term record of nss-sulfate and nitrate in aerosols on Midway Island, 1981-2000: Evidence of increased (now decreasing?) anthropogenic emissions form Asia, J. Geophys. Res., 108, 4019, doi:10.1029/2001JD001524, 2003.

Prospero, J. M., Uematsu, M., and Savoie, D.: Mineral aerosol transport to the Pacific Ocean, in Chemical Oceanography, edited by: Riley, J. P., Chester, R., and Duce, R. A., 10, 188-218, Academic, New York, USA, 1989.

Quinn, P. K. and Bates, T. S.: North America, Asian, and Indian haze: Similar regional impacts on climate?, Geophys. Res. Lett., 30, 1555, doi:10.1029/2003GL016934, 2003.

Quinn, P. K. and Bates, T. S.: Regional aerosol properties: Comparisons of boundary layer measurements form ACE 1, ACE 2, Aeroso199, INDOEX, ACE Asia, TARFOX, and NEAQS, J. Geophys. Res., 110, D14202, doi:10.1029/2004JD004755, 2005.

Ramanathan V., Crutzen P. J., Lelieveld J., Mitra A. P., Althausen D., Anderson J., Andreae M. O., Cantrell W., Cass G. R., Chung C. E., Clarke A. D., Coakley J. A., Collins W. D., Conant W. C., Dulac F., Heintzenberb J., Heymsfield A. J., Holben B., Howell S., Hudson J., Jayaraman A., Kiehl J. T., Krishnamurti T. N., Lubin D., McFarquhar G., Novakov T., Ogren J. A., Podgorny I. A., Prather K., Priestley K., Prospero J. M., Quinn P. K., Rajeev K., Rasch P., Rupert S., Sadourny R., Satheesh S. K., Shaw G. E., Sheridan P., and Valero F. P. J.: Indian Ocean Experiment: An integrated analysis of the climate forcing and effects of the great indo-Asian haze, J. Geophys. Res., 106, 28371-28398, 2001.

Rasch, P. J., Barth, M. C., Kiehl, J. T., Schwartz, S. E., and Benkovitz, C. M.: A description of the global sulfur cycle and its controlling processes in the National Center for Atmospheric Research Community Climate Model, Version3, J. Geophys. Res., 105, 1367-1385, 2000.

Rayner, N. A., Parker, D. E., Horton, E. B., Folland, C. K., Alexan- der, L. V., Rowell, D. P., Kent, E. C., and Kaplan, A.: Global analyses of sea surface temperature, sea ice, and night marine air temperature since the last nineteenth century, J. Geophys. Res., 108, 4407, doi:10.1029/2002JD002670, 2003.

Rodriguez, M. A. and Daddub, D.: IMAGES-SCAPE2: A modeling study of size- and chemically resolved aerosol thermodynamics in a global chemical transport model, J. Geophys. Res., 109, D02203, doi:10.1029/2003JD003639, 2004.

Roelofs, G. J., Lelieveld, J., and Ganzeveld, L.: Simulation of global sulfate distribution and the influence on effective cloud drop radii with a coupled photochemistry-sulfur cycle model, Tellus, 50B, 224-242, 1998.

Roelofs, G. J., Kasibhatla, P., Barrie, L., Bergmann, D., Bridgeman, C., Chin, M., Christensen, J., Easter, R., Feichter, J., Jeuken, A., Kjellstrom, E., Koch, D., Land, C., Lohmann, U., and Rasch, P.: Analysis of regional budgets of sulfur species modeled for the COSAM exercise, Tellus, 53B, 673-694, 2001.

Schulz, M., Textor, C., Kinne, S., Balkanski, Y., Bauer, S., Berntsen, T., Berglen, T., Boucher, O., Dentener, F., Guibert, S., Isaksen, I. S. A., Iversen, T., Koch, D., Kirkevåg, A., Liu, X., Montanaro, V., Myhre, G., Penner, J. E., Pitari, G., Reddy, S., Seland, Ø., Stier, P., and Takemura, T.: Radiative forcing by aerosols as derived from the AeroCom present-day and pre-industrial simulations, Atmos. Chem. Phys., 6, 5225-5246, doi:10.5194/acp-6-5225-2006, 2006.

Seinfeld, J. H. and Pandis, S. N.: Atmospheric Chemistry and Physics: from air Pollution to Climate Change, John Wiley, New York, USA, 1998.

Singh, H. B., Brune, W. H., Crawford, J. H., Jacob, D. J., and Russell, P. B.: Overview of the summer 2004 Intercontinental Chemical Transport Experiment - North America (INTEX-A), J. Geophys. Res., 111, D24S01, doi:10.1029/2006JD007905, 2006.

Singh, H. B., Brune, W. H., Crawford, J. H., Flocke, F., and Jacob, D. J.: Chemistry and transport of pollution over the Gulf of Mexico and the Pacific: spring 2006 INTEX-B campaign overview and first results, Atmos. Chem. Phys., 9, 2301-2318, doi:10.5194/acp-9-2301-2009, 2009.

Spiro, P. A., Jacob, D. J., and Logan, J. A.: Global inventory of sulfur emissions with $1^{\circ} \times 1^{\circ}$ resolution, J. Geophys. Res., 97, 6023-6036, 1992.

Spracklen, D. V., Pringle, K. J., Carslaw, K. S., Chipperfield, M. P., and Mann, G. W.: A global off-line model of sizeresolved aerosol microphysics: I. Model development and prediction of aerosol properties, Atmos. Chem. Phys., 5, 2227 2252, doi:10.5194/acp-5-2227-2005, 2005.

Stier, P., Feichter, J., Kinne, S., Kloster, S., Vignati, E., Wilson, J., Ganzeveld, L., Tegen, I., Werner, M., Balkanski, Y., Schulz, M., Boucher, O., Minikin, A., and Petzold, A.: The aerosolclimate model ECHAM5-HAM, Atmos. Chem. Phys., 5, 11251156, doi:10.5194/acp-5-1125-2005, 2005.

Streets, D. G., Bond, T. C., Carmichael, G. R., Fernandes, S. D., Fu, Q., He, D., Klimont, Z., Nelson, S. M., Tsai, N. Y., Wang, M. Q., Woo, J.-H., Yarber, K. F.: An inventory of gaseous and primary aerosol emissions in Asia in the year 2000, J. Geophys. Res., 108, 8809, doi:10.1029/2002JD003093, 2003.

Sudo, K., Takahashi, M., Kurokawa, J., and Akimoto, H.: CHASER: A global chemical model of the troposphere: 1. Model description, J. Geophys. Res., 107, 4339, doi:10.1029/2001JD001113, 2002. 
Suzuki, K., Nakajima, T., Numaguti, A., Takemura, T., Kawamoto, K., and Higurashi, A.: A study of the aerosol effect on a cloud field with simultaneous use of GCM modeling and satellite observation, J. Atmos. Sci., 61, 179-194, 2004.

Takemura, T., Okamoto, H., Maruyama, Y., Numaguti, A., Higurashi, A., and Nakajima, T.: Global three-dimensional simulation of aerosol optical thickness distribution of various origins, J. Geophys. Res., 105, 17853-17873, 2000.

Takemura, T., Nakajima, T., Dubovik, O., Holben, B. N., and Kinne, S.: Single scattering albedo and radiative forcing of various aerosol species with a global three-dimensional model, J. Climate, 15, 333-352, 2002.

Takemura, T., Nozawa, T., Emori, S., Nakajima, T. Y., and Nakajima, T.: Simulation of climate response to aerosol direct and indirect effects with aerosol transport-radiation model, J. Geophys. Res., 110, D02202, doi:10.1029/2004JD005029, 2005.

Textor, C., Schulz, M., Guibert, S., Kinne, S., Balkanski, Y., Bauer, S., Berntsen, T., Berglen, T., Boucher, O., Chin, M., Dentener, F., Diehl, T., Easter, R., Feichter, H., Fillmore, D., Ghan, S., Ginoux, P., Gong, S., Grini, A., Hendricks, J., Horowitz, L., Huang, P., Isaksen, I., Iversen, I., Kloster, S., Koch, D., Kirkevåg, A., Kristjansson, J. E., Krol, M., Lauer, A., Lamarque, J. F., Liu, X., Montanaro, V., Myhre, G., Penner, J., Pitari, G., Reddy, S., Seland, Ø., Stier, P., Takemura, T., and Tie, X.: Analysis and quantification of the diversities of aerosol life cycles within AeroCom, Atmos. Chem. Phys., 6, 1777-1813, doi:10.5194/acp-61777-2006, 2006.

Textor, C., Schulz, M., Guibert, S., Kinne, S., Balkanski, Y., Bauer, S., Berntsen, T., Berglen, T., Boucher, O., Chin, M., Dentener, F., Diehl, T., Feichter, J., Fillmore, D., Ginoux, P., Gong, S., Grini, A., Hendricks, J., Horowitz, L., Huang, P., Isaksen, I. S. A., Iversen, T., Kloster, S., Koch, D., Kirkevåg, A., Kristjansson, J. E., Krol, M., Lauer, A., Lamarque, J. F., Liu, X., Montanaro, V., Myhre, G., Penner, J. E., Pitari, G., Reddy, M. S., Seland, Ø., Stier, P., Takemura, T., and Tie, X.: The effect of harmonized emissions on aerosol properties in global models an AeroCom experiment, Atmos. Chem. Phys., 7, 4489-4501, doi:10.5194/acp-7-4489-2007, 2007.
Tie, X., Madronich, S., Walters, S., Edwards, D. P., Ginoux, P., Mahowald, N., Zhang, R. Y., Lou, C., and Brasseur, G.: Assessment of the global impact of aerosols on tropospheric oxidants, J. Geophys. Res., 110, D03204, doi:10.1029/2004JD005359, 2005.

Verma, S., Boucher, O., Reddy, M. S., Upadhyaya, H. C., Le. Van, P., Binkowski, F. S., and Sharma, O. P.: Modeling and analysis of aerosol processes in aninteractive chemistry general circulation model, J. Geophys. Res., 112, D03207, doi:10.1029/2005JD006077, 2007.

Wen, G., Marshak, A., Cahalan, R. F., Remer, L. A., and Kleidman, R. G.: 3-D aerosol-cloud radiative interaction observed in collocated MODIS and ASTER images of cumulus cloud fields, J. Geophys. Res., 112, D13204, doi:10.1029/2006JD008267, 2007.

Wesely, M. L.: Parameterization of surface resistances to gaseous dry deposition in regional-scale numerical models, Atmos. Environ., 23, 1293-1304, 1989.

Winker, D. M.: Understanding aerosol and cloud radiative effects using observations from CALIPSO and the A-Train: Progress and prospects, International Radiation Symposium 2008, Iguacu, Brazil, 2008.

Yu, H., Kaufman, Y. J., Chin, M., Feingold, G., Remer, L. A., Anderson, T. L., Balkanski, Y., Bellouin, N., Boucher, O., Christopher, S., DeCola, P., Kahn, R., Koch, D., Loeb, N., Reddy, M. S., Schulz, M., Takemura, T., and Zhou, M.: A review of measurement-based assessments of the aerosol direct radiative effect and forcing, Atmos. Chem. Phys., 6, 613-666, doi:10.5194/acp-6-613-2006, 2006.

Zhang, L., Gong, S., Padro, J., and Barrie, L.: A size-segregated particle dry deposition scheme for an atmospheric aerosol module, Atmos. Environ., 35, 549-560, 2001. 